\title{
1 The evolution of knowledge on genes associated with human diseases
}

2

3 Thomaz Lüscher-Dias ${ }^{1}$, Rodrigo Juliani Siqueira Dalmolin ${ }^{2,3}$, Paulo de Paiva Amaral ${ }^{4}$, Tiago

4 Lubiana Alves $^{4}$, Viviane Schuch ${ }^{4}$, Glória Regina Franco ${ }^{1}$, Helder I Nakaya ${ }^{4,5,6^{*}}$.

5

$6{ }^{1}$ Department of Biochemistry and Immunology, Institute of Biological Sciences, Federal

7 University of Minas Gerais, Belo Horizonte, MG, Brazil;

$8{ }^{2}$ Bioinformatics Multidisciplinary Environment-BioME, IMD, Federal University of Rio Grande

9 do Norte, Natal, RN, Brazil;

$10{ }^{3}$ Department of Biochemistry, CB, Federal University of Rio Grande do Norte, Natal, RN, Brazil;

$1{ }^{4}$ Department of Clinical and Toxicological Analyses, School of Pharmaceutical Sciences,

12 University of São Paulo, São Paulo, Brazil;

$13{ }^{5}$ Hospital Israelita Albert Einstein, São Paulo, Brazil.

$14{ }^{6}$ Scientific Platform Pasteur-University of São Paulo, São Paulo, Brazil

16 *Correspondence to: hnakaya@usp.br 
medRxiv preprint doi: https://doi.org/10.1101/2021.06.16.21259049; this version posted June 21, 2021. The copyright holder for this preprint (which was not certified by peer review) is the author/funder, who has granted medRxiv a license to display the preprint in perpetuity.

It is made available under a CC-BY-NC-ND 4.0 International license .

\section{Abstract}

18 Thousands of scientific articles describing genes associated with human diseases are published 19 every week. Computational methods such as text mining and machine learning algorithms are 20 now able to automatically detect these associations. In this study, we used a cognitive 21 computing text-mining application to construct a knowledge network comprised of 3,723 genes 22 and 99 diseases. We then tracked the yearly changes on these networks to analyze how our 23 knowledge has evolved in the past 30 years. Our approach helped to unravel the molecular

24 bases of diseases over time, and to detect shared mechanisms between clinically distinct 25 diseases. It also revealed that multi-purpose therapeutic drugs target genes which are 26 commonly associated with several psychiatric, inflammatory, or infectious disorders. By 27 navigating in this knowledge tsunami, we were able to extract relevant biological information 28 and insights about human diseases.

30 Keywords: meta-research, evolution of knowledge, genes, human diseases, network analysis 
medRxiv preprint doi: https://doi.org/10.1101/2021.06.16.21259049; this version posted June 21, 2021. The copyright holder for this preprint (which was not certified by peer review) is the author/funder, who has granted medRxiv a license to display the preprint in perpetuity.

It is made available under a CC-BY-NC-ND 4.0 International license .

\section{Introduction}

Thousands of scientific articles are published every day, piling up with millions of already published papers (Fortunato et al., 2018). Keeping abreast of scientific significance has become an overwhelming task for researchers in their own fields and in other areas of science. In this scenario, computational methods such as text mining, machine learning, and cognitive computing are helping scientists to summarize published scientific literature. Recently, machine learning approaches have been used to analyze and integrate a variety of biological and medical data (Littmann et al., 2020; Zitnik et al., 2019). These include methods that integrate electronic health records (Rajkomar et al., 2018), capture latent knowledge from the material science literature (Tshitoyan et al., 2019), and discover potential novel drugs to treat psychiatric and neurological disorders using cognitive computing and network medicine analysis of the medical literature (Lüscher Dias et al., 2020).

Particularly, the field of molecular biology has seen a remarkable increase in the number of new studies in recent decades. This has resulted in a large number of genes associated with diseases. As a positive consequence of this efflux of genetic knowledge, diseases that were previously not known to have common etiologies are now being connected through their shared alterations in gene expression and interaction patterns, which has opened many potential new roads for clinical advances (Brooks et al., 2014; Carson et al., 2017; Lees et al., 2011; Postma et al., 2011). One significant example of this trend is the association between psychiatric disorders and immune-related diseases (Gibney and Drexhage, 2013; Marrie et al., 2017; Wang et al., 2015).

Network medicine (Barabási et al., 2011), a contemporary approach to studying relationships between genes and diseases, has also been made possible because of the large 
medRxiv preprint doi: https://doi.org/10.1101/2021.06.16.21259049; this version posted June 21, 2021. The copyright holder for this preprint (which was not certified by peer review) is the author/funder, who has granted medRxiv a license to display the preprint in perpetuity.

It is made available under a CC-BY-NC-ND 4.0 International license .

54 amounts of data on genes and diseases available online. Moreover, knowledge networks, that 55 is, complex graphs that connect concepts according to the established knowledge, can be 56 analyzed under the network medicine framework to produce novel insights from medical 57 knowledge (Bai et al., 2016; Lüscher Dias et al., 2020).

58 In this study, we used IBM Watson for Drug Discovery (WDD; Y. Chen et al., 2016), a 59 cognitive computing text-mining application, to extract known relationships between genes and 60 psychiatric, inflammatory, and infectious diseases from the peer-reviewed literature published

61 between 1990 and 2018. We developed knowledge networks of genes and diseases and 62 monitored the evolution of these relationships yearly. We then quantified and described how 63 genes were connected to each category of disease over this period and how key biological 64 functions unraveled as new genes were added to the network. We also found pairs of diseases 65 from different categories that significantly share genes with each other, indicating underlying 66 clinical proximity between diseases that have not been historically related. Lastly, we explored 67 the genes that were common to all psychiatric, inflammatory, or infectious diseases and 68 investigated which drugs target them. By using a network medicine approach, we were able to 69 extract relevant biological information and new insights of genes, pathways, and therapeutic 70 drugs associated with complex human disorders. 
medRxiv preprint doi: https://doi.org/10.1101/2021.06.16.21259049; this version posted June 21, 2021. The copyright holder for this preprint (which was not certified by peer review) is the author/funder, who has granted medRxiv a license to display the preprint in perpetuity.

It is made available under a CC-BY-NC-ND 4.0 International license .

\section{Results}

\section{Evolution of knowledge on the molecular bases of human diseases.}

We used WDD, a cognitive computing text-mining application, to identify connections between genes and diseases in millions of peer-reviewed studies (Y. Chen et al., 2016). For each year from 1990 to 2018, we queried WDD to obtain gene sets related to 99 inflammatory, psychiatric, and infectious diseases (Table S1). WDD detects terms of interest, such as genes and diseases, in scientific texts (e.g., PubMed abstracts and full text journal articles) and finds contextual elements connecting them (e.g., prepositions and verbs). These connections can be extracted from many distinct sources of evidence such as gene expression alterations, genomewide association studies, or protein expression experiments. A confidence score is established for each relationship based on the strength of the detected semantic association and also the number of documents in which the connection is found. However, the type of study from which the association is obtained is not considered for the calculation of the evidence score. Here, we kept only gene-disease relationships with a confidence score equal or higher than $50 \%$, and which were supported by at least 2 studies.

Next, we built yearly disease-disease networks connecting inflammatory, infectious, and

87 psychiatric diseases according to the significance of the genes shared by each pair of diseases

88 (Fig. 1A). These networks were cumulative: the 2018 network (Fig. 1A, rightmost network) 89 displays all connections found in the entire period, while the 2000 network (Fig. 1A, second 90 network from left to right), for instance, contains all connections from 1990 up to that year. The 911990 network (Fig. 1A, leftmost network) depicts the relationships between diseases from the 92 beginning of the literature registries up to 1990. 
medRxiv preprint doi: https://doi.org/10.1101/2021.06.16.21259049; this version posted June 21, 2021. The copyright holder for this preprint (which was not certified by peer review) is the author/funder, who has granted medRxiv a license to display the preprint in perpetuity.

\section{It is made available under a CC-BY-NC-ND 4.0 International license .}

A 1990
2000

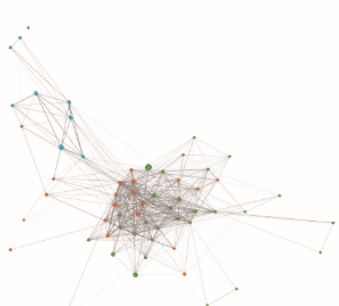

2010

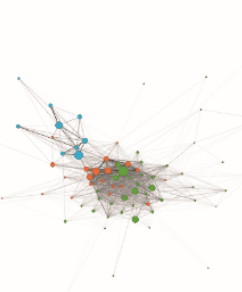

2018

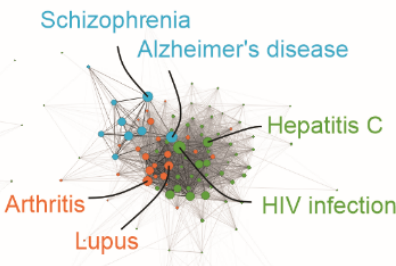

Categories

Inflammatory Psychiatric
B

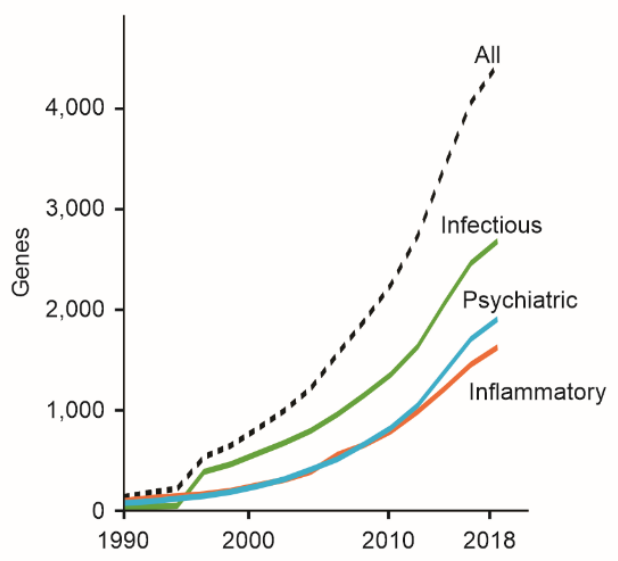

C

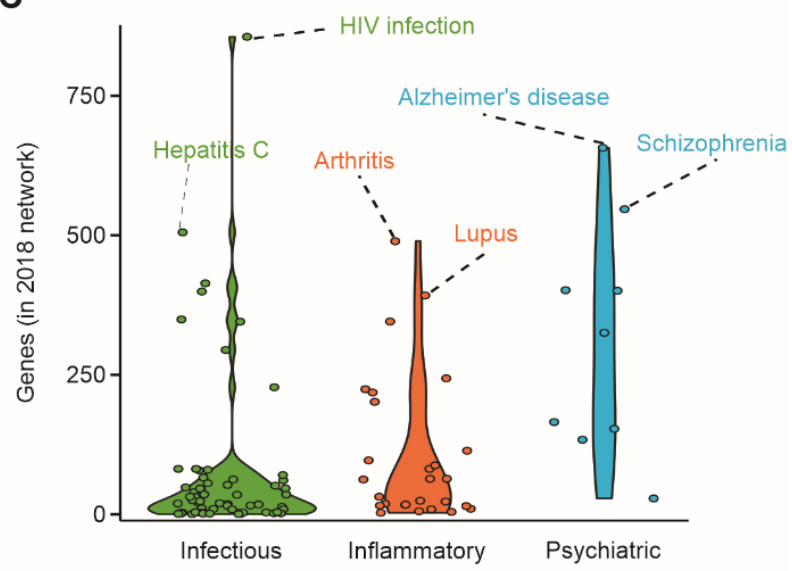

D
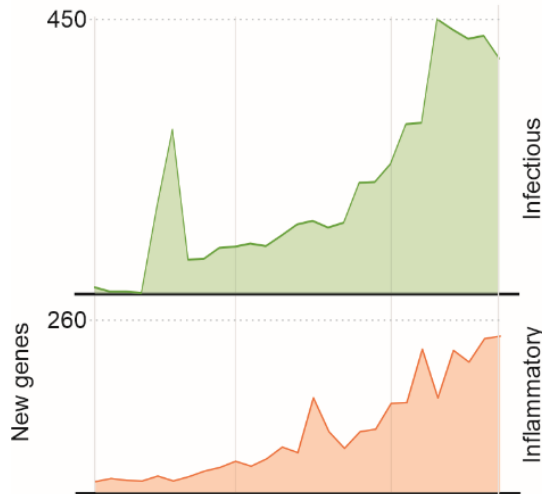

94

E

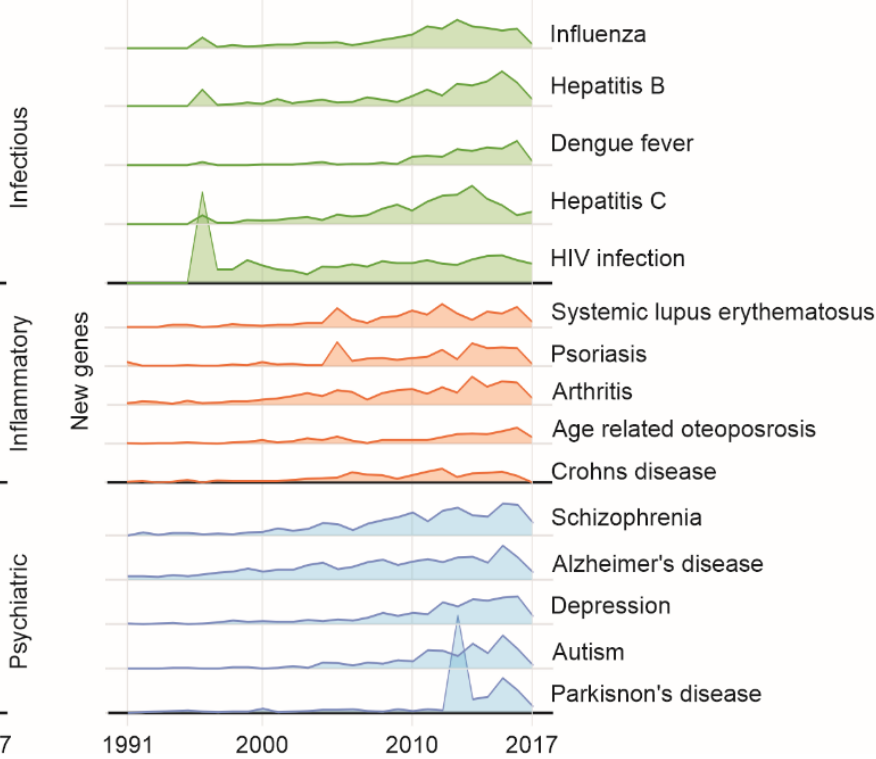

6 
medRxiv preprint doi: https://doi.org/10.1101/2021.06.16.21259049; this version posted June 21, 2021. The copyright holder for this preprint (which was not certified by peer review) is the author/funder, who has granted medRxiv a license to display the preprint in perpetuity.

It is made available under a CC-BY-NC-ND 4.0 International license .

95 Figure 1. Evolution of knowledge on the molecular bases of human diseases. A. Disease-

96 disease knowledge network on infectious, inflammatory, and psychiatric disorders from 1990 to

97 2018. Nodes represent diseases and are proportional to the number of genes associated with

98 each disease in each year. Edge weights are proportional to the significance of gene-sharing

99 between each pair of diseases. Only edges with a p-value $<0.01$ are depicted. B. Cumulative

100 number of genes associated with each disease category and with all diseases from 1990 to

101 2018. C. Distribution of the number of genes associated with each disease and category in

102 2018. D. Number of new genes added to the network in each category per year. E. Number of

103 new genes added to the network in selected diseases each year. Color code: Green -

104 infectious diseases, orange - inflammatory diseases, and blue - psychiatric disorders.

105

106

We then assessed how these relationships evolved over the past three decades (19902018) and explored the historical trends of the new genes connected to the network during the period (Fig. 1B-E and Table S2). In 1990, only 95 genes were connected in the network (Fig. 1B), and no association between psychiatric disorders and inflammatory or infectious diseases could be established through shared genes (Fig. 1A). Accordingly, the overall similarity between

111 diseases (between or within categories) was low in 1990 (Fig. S1). From 1990 to 2010, with the

112 constant increase in the number of genes associated with diseases in all categories, a 113 preliminary approximation between inflammatory and infectious diseases was observed (Fig.

114 1A, second panel, and Fig. S1A). During the next 9 years (2010 to 2018), the new genes added

115 to the network (Fig. 1B) resulted in a strengthening of the connections between infectious and 116 inflammatory diseases, and a fast approximation between psychiatric disorders and the other

117 two categories (Fig. 1A, fourth panel, and Fig. S1A). Meanwhile, the proximity of diseases within 
medRxiv preprint doi: https://doi.org/10.1101/2021.06.16.21259049; this version posted June 21, 2021. The copyright holder for this preprint (which was not certified by peer review) is the author/funder, who has granted medRxiv a license to display the preprint in perpetuity.

It is made available under a CC-BY-NC-ND 4.0 International license .

118 the same categories also increased (Fig. S1B). Inflammatory diseases occupy a central position

119 in the 2018 network (Fig. 1A, fourth panel), which reflects their high between- and within-

120 category similarities sustained throughout the 30-year period (Fig. S1). Psychiatric and

121 infectious diseases presented the lowest similarity between each other (Figs. 1A and S1).

122

A

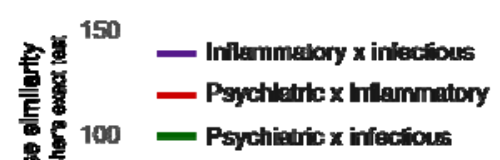

123

124

125

126

127

128

129

130

131

132

133

134
B

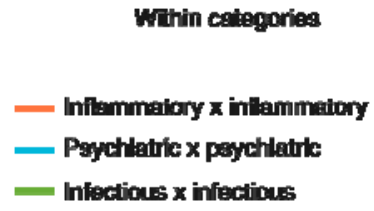

Infectious $\mathbf{x}$ infectious

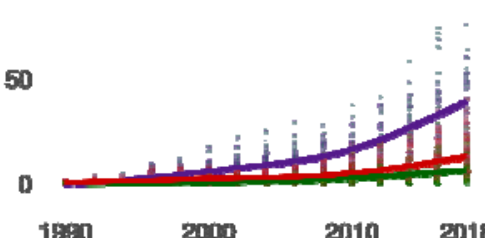

1900

2000

$2010 \quad 2018$

$1980 \quad 2000 \quad 2010 \quad 2018$

Year

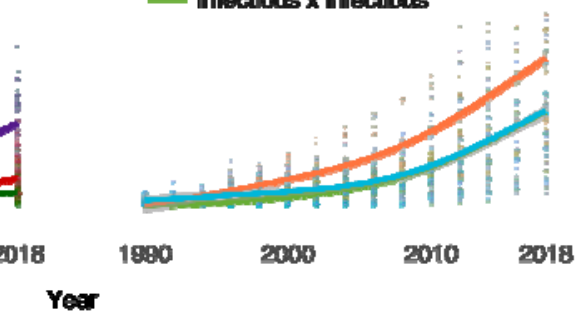

rar

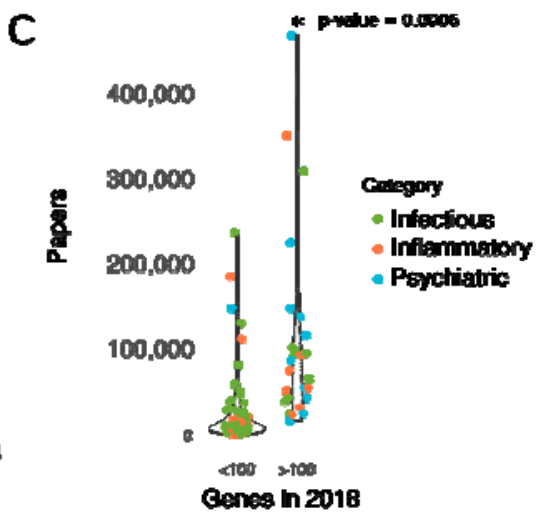

Figure S1. Evolution of knowledge - supplementary results. A and B. Evolution of the mean disease-disease similarity between diseases of different categories (A) or within diseases of the same categories (B). C. Comparison of the total number of papers retrieved from PubMed on diseases of all categories that were connected to less than 100 genes in the 2018 network with that connected to more than 100 genes in 2018 . The $p$-value is obtained from the t-test of the mean comparison between the two distributions.

In 2018, a total of 3,723 genes were present in the network (Fig. 1B). The number of genes associated with each disease in the three different categories in 2018 also varied (Fig. 1C). The infectious diseases with the highest number of connected genes in 2018 were hepatitis B (414 genes), hepatitis C (506 genes), and HIV infection (856 genes; Fig. 1C). However, 55 of 
medRxiv preprint doi: https://doi.org/10.1101/2021.06.16.21259049; this version posted June 21, 2021. The copyright holder for this preprint (which was not certified by peer review) is the author/funder, who has granted medRxiv a license to display the preprint in perpetuity.

It is made available under a CC-BY-NC-ND 4.0 International license .

13563 infectious diseases were connected to less than 100 genes in 2018 (Fig. 1C). The most

136 connected inflammatory diseases were psoriasis (346 genes), systemic lupus erythematosus

137 (393 genes), and arthritis (490 genes; Fig. 1C). In the category of psychiatric disorders,

138 Alzheimer's disease was the most connected (657 genes), followed by schizophrenia (547

139 genes) and depression (402 genes; Fig. 1B). The imbalance in the distribution of genes

140 connected to infectious diseases likely reflects a bias in the research interest toward the

141 discovery of genes related to diseases already connected to more genes. In fact, the 2018

142 network showed that the number of scientific papers that mentioned poorly connected diseases

143 (less than 100 genes) is significantly lower than the number of papers published on highly

144 connected diseases (more than 100 genes) (Fig. S1C).

145 Distinct historical trends of discovery were seen for each disease category (Fig. 1D and

146 Table S3). Prominent peaks of gene-association discovery occurred in 1996 for infectious

147 diseases, in 2005 for inflammatory diseases, and in 2013 for psychiatric disorders (Fig. 1C).

148 From 2010 to 2017, the rate of gene discovery in all three categories increased (Fig. 1C). The

149 significant increase in the number of genes associated with infectious diseases observed in

1501996 was mostly driven by 154 new genes associated with HIV infection (Fig. 1D), which

151 corresponded to $50 \%$ of the new genes added to the network in that year (Table S3). The triple

152 therapy for HIV using nucleoside reverse-transcriptase inhibitors and protease inhibitors was

153 established in 1996 (Hammer et al., 1996), which likely influenced this outburst of genetic

154 discovery. The 2005 increase in the number of genes associated with inflammatory diseases

155 was mostly related to the new genes connected to psoriasis (41 genes) and systemic lupus

156 erythematosus (33 genes; Fig. 1D), which together corresponded to $20 \%$ of the new genes

157 associated with all of the diseases in 2005 (Table S3). The $\mathrm{Th}_{17}$ cell lineage was discovered in 
medRxiv preprint doi: https://doi.org/10.1101/2021.06.16.21259049; this version posted June 21, 2021. The copyright holder for this preprint (which was not certified by peer review) is the author/funder, who has granted medRxiv a license to display the preprint in perpetuity.

It is made available under a CC-BY-NC-ND 4.0 International license .

1582005 (Langrish et al., 2005), a cell type that has since been strongly associated with

159 autoimmune and infectious diseases (Zambrano-Zaragoza et al., 2014). In 2013, a large

160 number of new genes were associated with Parkinson's disease (165 genes Fig. 1D), which

161 corresponded to $17 \%$ of the new genes in the network in that year (Table S3). We could not

162 detect any specific scientific landmark in 2013 that could explain this peak. Nevertheless,

163 important genes related to the innate immune response to pathogens and inflammation are

164 among the new genes associated with Parkinson's disease in 2013, such as interleukin 1 beta

165 (IL1B) and the p105 subunit of the nuclear factor kappa B (NFKB1).

166

167 Evolution of disease relationships between categories

168 Next, we investigated the evolution of the similarity between diseases from different 169 categories according to their shared genes (see Methods section). For the top 9 most 170 connected diseases of each category in 2018 (i.e., diseases connected to more genes), we 171 detected the diseases from the other two categories with the most significant gene sharing 172 between them and analyzed how these relationships evolved from 1990 to 2018 (Figs. 2, S2, 173 S3, and S4). Alzheimer's disease was the psychiatric disorder with the highest similarity to 174 inflammatory diseases in 2018, including arthritis and systemic lupus erythematosus (Fig. 2A). 175 The relationships between Alzheimer's disease and these disorders grew steadily in 176 significance from 1990 to 2018 (Fig. S2A), which captures the now well-established relevance of 177 inflammatory processes in the pathophysiology of Alzheimer's disease (Newcombe et al., 2018).

178 Surprisingly, fibromyalgia was similar to several psychiatric diseases: depression, anxiety, 179 bipolar disorder, schizophrenia, and Huntington's disease (Figs. 2A and S2). The total number 180 of genes associated with fibromyalgia in 2018 was low ( 25 genes), but $72 \%$ of these (17 genes) 
medRxiv preprint doi: https://doi.org/10.1101/2021.06.16.21259049; this version posted June 21, 2021. The copyright holder for this preprint (which was not certified by peer review) is the author/funder, who has granted medRxiv a license to display the preprint in perpetuity. It is made available under a CC-BY-NC-ND 4.0 International license .

181 are also associated with depression. These are genes related to nervous system development, 182 such as brain derived neurotrophic factor (BDNF), nerve growth factor (NGF), and neuropeptide $183 \mathrm{Y}$ (NPY), and inflammatory response, including interleukin 6 (IL6), C-X-C motif chemokine 184 ligand 8 (CXCL8), and tumor necrosis factor (TNF). In fact, fibromyalgia patients often present 185 psychiatric comorbidities such as depression and anxiety (Galvez-Sánchez et al., 2020). 
medRxiv preprint doi: https://doi.org/10.1101/2021.06.16.21259049; this version posted June 21, 2021. The copyright holder for this preprint (which was not certified by peer review) is the author/funder, who has granted medRxiv a license to display the preprint in perpetuity.

It is made available under a CC-BY-NC-ND 4.0 International license .

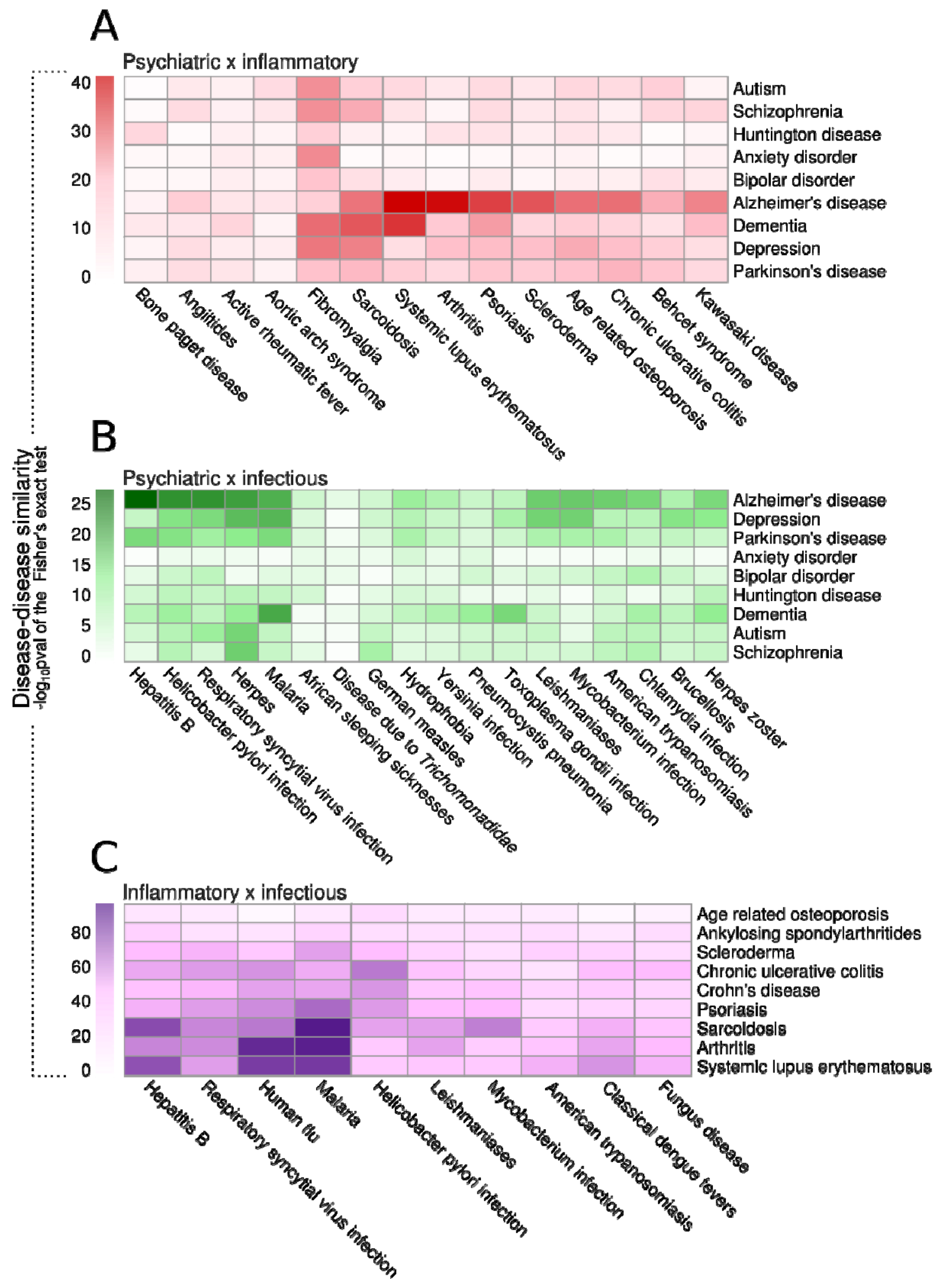


medRxiv preprint doi: https://doi.org/10.1101/2021.06.16.21259049; this version posted June 21, 2021. The copyright holder for this preprint (which was not certified by peer review) is the author/funder, who has granted medRxiv a license to display the preprint in perpetuity.

It is made available under a CC-BY-NC-ND 4.0 International license .

187 Figure 2. Evolution of disease relationships between categories. A. Disease-disease

188 similarity between diseases of different categories in the 2018 network according to their shared

189 genes. The similarity score was defined as the $-\log _{10}$ pval of the Fisher's exact test result of the

190 gene overlap between each disease pair. Each heatmap represents the similarity score

191 between diseases of two different categories: A. psychiatric versus inflammatory diseases. B.

192 psychiatric versus infectious diseases. C. inflammatory versus infectious diseases.

193

194 Among infectious diseases, herpes was the most similar disease to autism, 195 schizophrenia, and Huntington's disease and was also among the top 5 most similar infectious 196 diseases to depression, Parkinson's disease, and Alzheimer's disease (Figs. 2B and S3). 197 Herpes infection might be associated with the development of Alzheimer's disease (Harris and 198 Harris, 2015); the typical amyloid- $\beta$ deposition that occurs in the brain of Alzheimer's disease 199 patients could be an innate immunity mechanism to fight herpes virus infections (Eimer et al., 200 2018). Our results indicate that there has been latent evidence of that association since the 201 early 2000s in the scientific literature (Fig. S3A). In the 2005 network, Alzheimer's disease and 202 herpes virus infection shared 14 genes, which represented 58\% of the known genes associated 203 with herpes infection at that time. 
medRxiv preprint doi: https://doi.org/10.1101/2021.06.16.21259049; this version posted June 21, 2021. The copyright holder for this preprint (which was not certified by peer review) is the author/funder, who has granted medRxiv a license to display the preprint in perpetuity.

It is made available under a CC-BY-NC-ND 4.0 International license .

\section{Psychiatric vs. inflammatory}

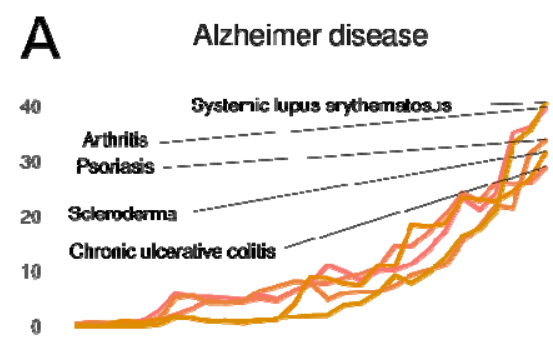

B Anxiety disorder

C Autism

D Bipolar affective psychosis

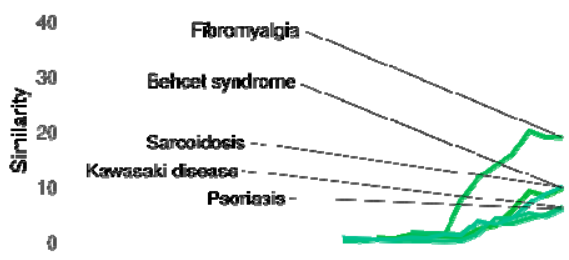

$\mathbf{G} \quad$ Huntington disease

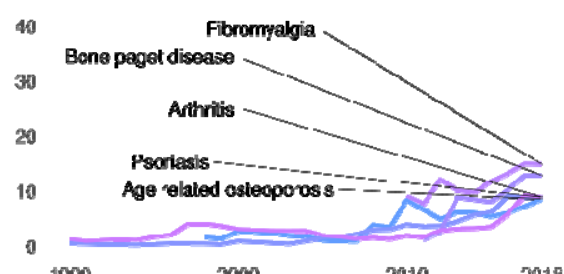

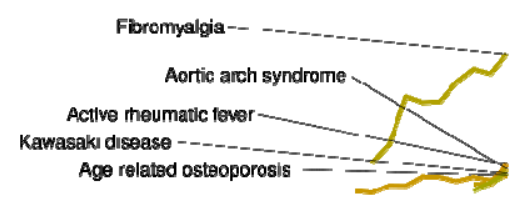

E Dementia

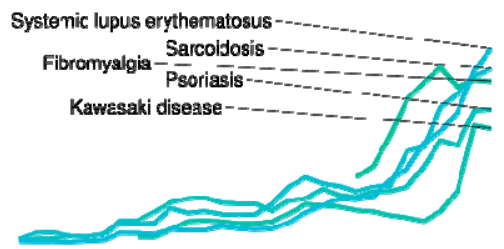

H Parkinson's disease

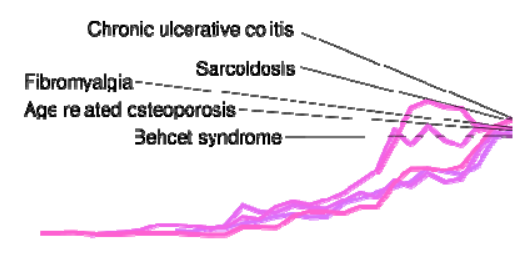

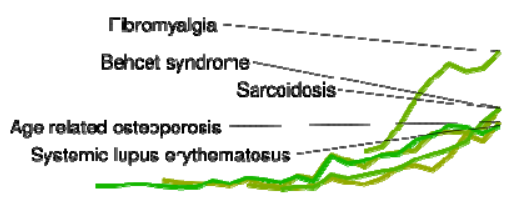

F

Depression

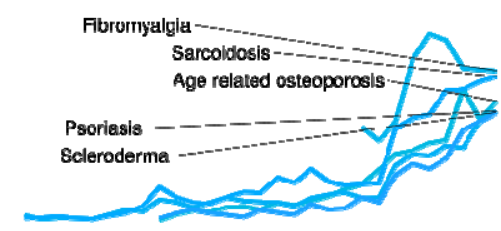

Schizophrenia

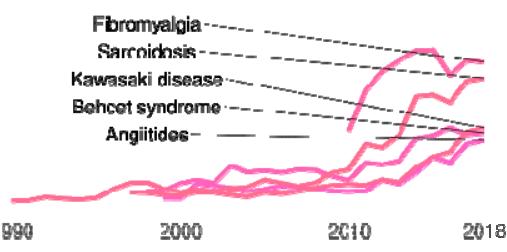

Figure S2. Disease-disease similarity evolution between psychiatric and inflammatory

diseases from 1990 to 2018. A-I. Evolution of the similarity between psychiatric disorders and inflammatory diseases: Alzheimer's disease (A), anxiety disorder (B), autism (C), bipolar

210 disorder (D), dementia (E), depression (F), Huntington's disease (G), Parkinson's disease (H), 211 and schizophrenia (I). Similarity scores represent the $-\log _{10}$ pval of the Fisher's exact test result 212 of the gene overlap between each disease pair in each year from 1990 to 2018. 
medRxiv preprint doi: https://doi.org/10.1101/2021.06.16.21259049; this version posted June 21, 2021. The copyright holder for this preprint (which was not certified by peer review) is the author/funder, who has granted medRxiv a license to display the preprint in perpetuity.

It is made available under a CC-BY-NC-ND 4.0 International license .

\section{Psychiatric vs. infectious}
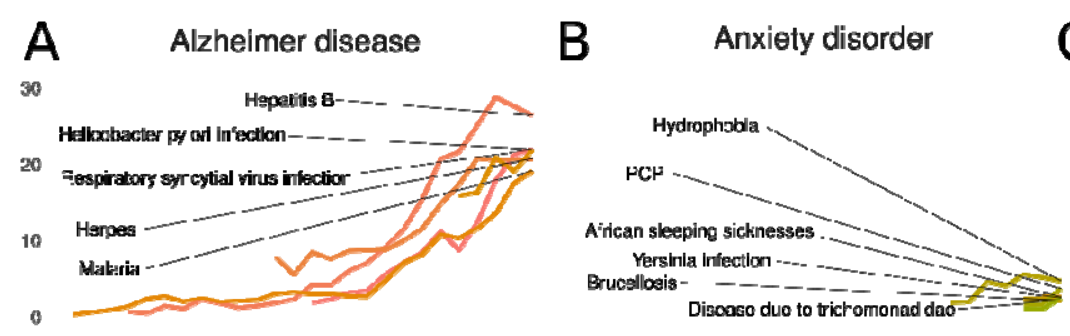

C Autism

D Bipolar affective psychosis $\quad \mathrm{E}$

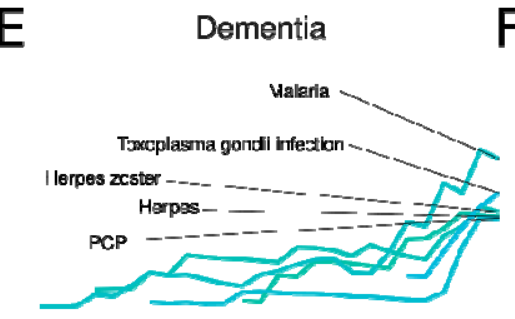

0

sh

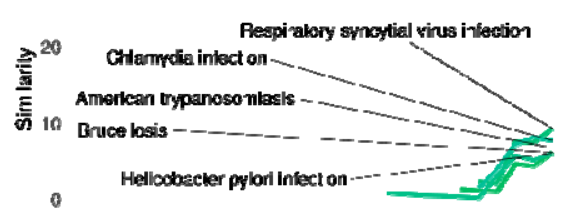

G Huntington disease

30
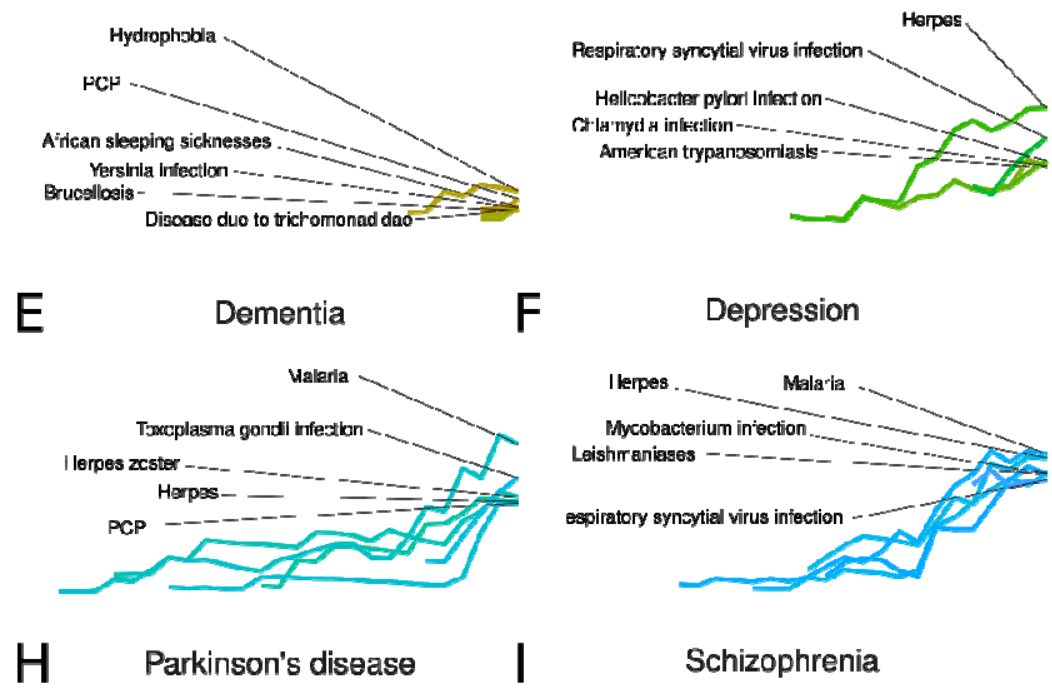

213
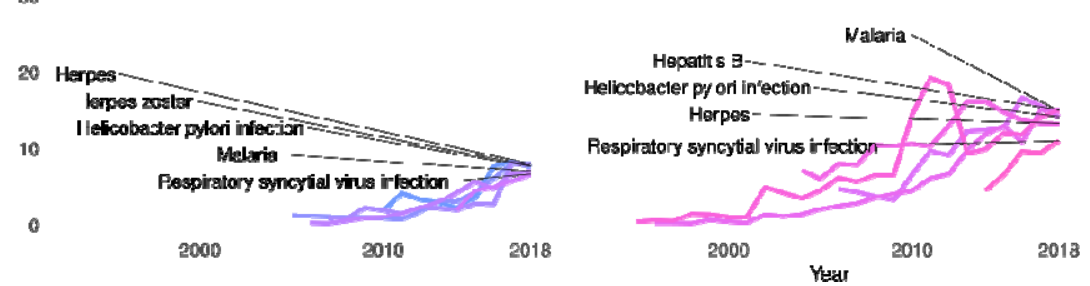

F Depression

214

215 Figure S3. Disease-disease similarity evolution between psychiatric and infectious

216 diseases from 1990 to 2018. A-I. Evolution of the similarity between psychiatric disorders and

217 infectious diseases: Alzheimer's disease (A), anxiety disorder (B), autism (C), bipolar disorder

218 (D), dementia (E), depression (F), Huntington's disease (G), Parkinson's disease (H), and 219 schizophrenia (I). Similarity scores represent the $-\log _{10}$ pval of the Fisher's exact test result of 220 the gene overlap between each disease pair in each year from 1990 to 2018. 
medRxiv preprint doi: https://doi.org/10.1101/2021.06.16.21259049; this version posted June 21, 2021. The copyright holder for this preprint (which was not certified by peer review) is the author/funder, who has granted medRxiv a license to display the preprint in perpetuity. It is made available under a CC-BY-NC-ND 4.0 International license.

Autoimmune inflammatory diseases, such as systemic lupus erythematosus, arthritis, 223 and psoriasis, also showed strong gene sharing with viral infections such as hepatitis B and C, 224 respiratory syncytial virus (RSV) infection, influenza, and HIV (Figs. 2C and S4). The 225 association between viral infections and autoimmune diseases is well documented (Getts et al., 226 2013). For instance, the SARS-CoV-2 virus can trigger Guillain-Barré syndrome, a neurological 227 autoimmune disease, in COVID-19 patients (Dalakas, 2020). Dengue patients also present a 228 higher risk of developing autoimmune diseases, such as systemic lupus erythematosus and vasculitis (Li et al., 2018), an association that was also captured in our analysis of the scientific literature since the late 1990s (Fig. S4I). 
medRxiv preprint doi: https://doi.org/10.1101/2021.06.16.21259049; this version posted June 21, 2021. The copyright holder for this preprint (which was not certified by peer review) is the author/funder, who has granted medRxiv a license to display the preprint in perpetuity.

It is made available under a CC-BY-NC-ND 4.0 International license .

\section{Inflammatory vs. infectious}
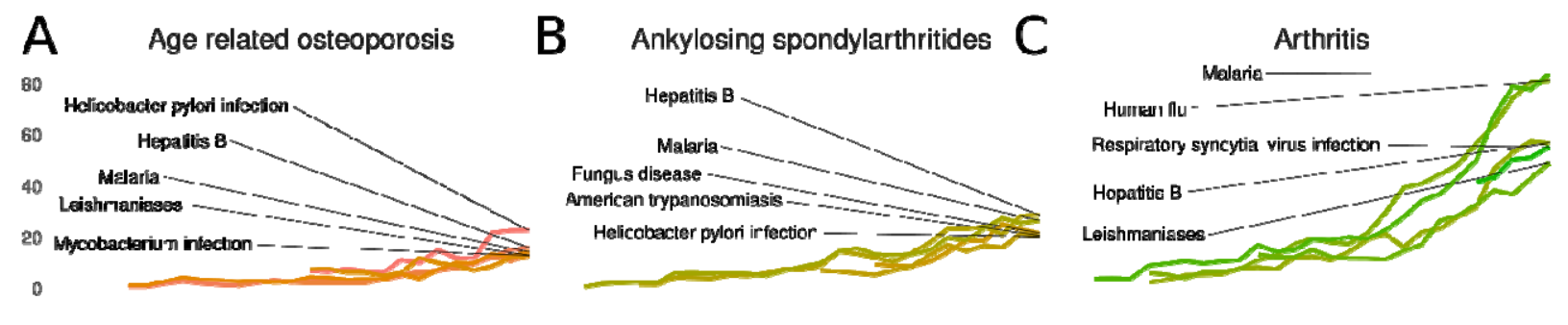

D Chronic ulcerative colitis E

E Crohn's disease F

Psoriasis
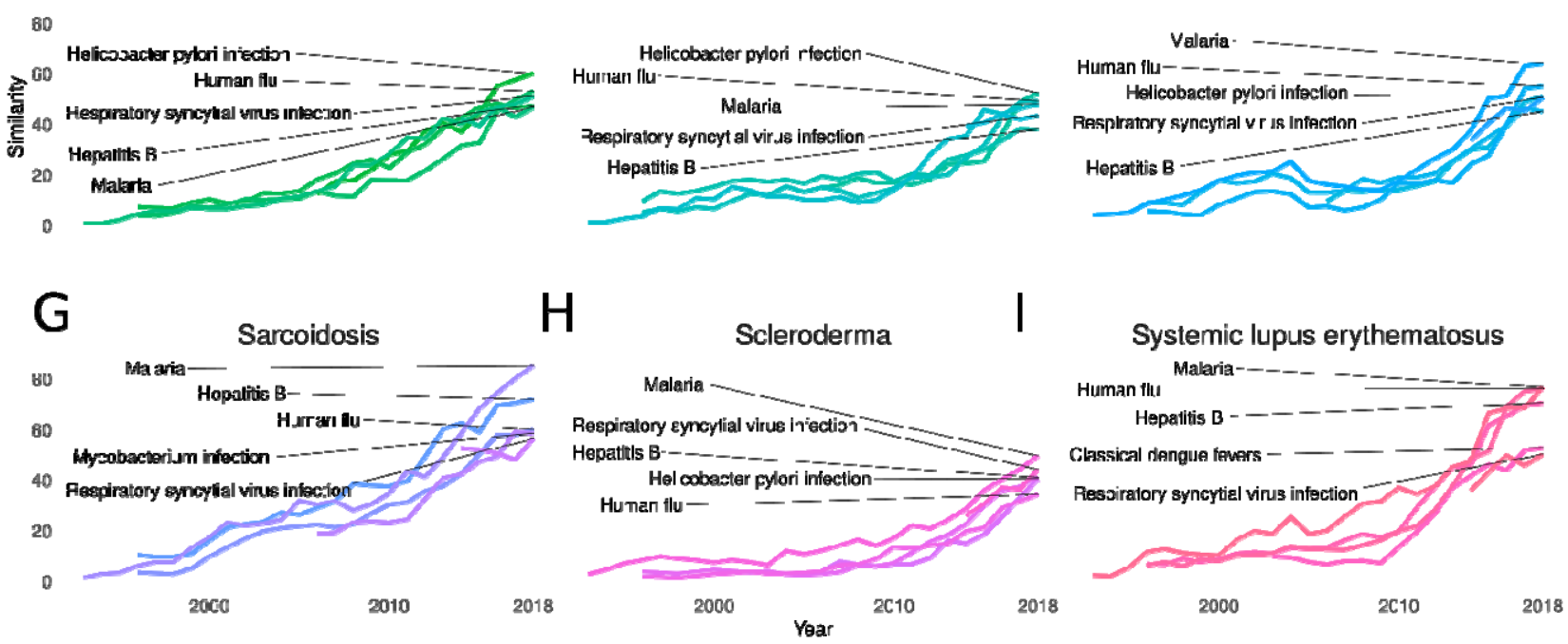

\section{Figure S4. Disease-disease similarity evolution between inflammatory and infectious}

235 diseases from 1990 to 2018. A-I. Evolution of the similarity between psychiatric disorders and 236 infectious diseases: age related osteoporosis (A), ankylosing spondylarthritides (B), arthritis (C),

237 chronic ulcerative colitis (D), Crohn's disease (E), psoriasis (F), sarcoidosis (G), scleroderma

$238(\mathbf{H})$, and systemic lupus erythematosus (I). Similarity scores represent the - $\log _{10}$ pval of the

239 Fisher's exact test result of the gene overlap between each disease pair in each year from 1990

240 to 2018. 
medRxiv preprint doi: https://doi.org/10.1101/2021.06.16.21259049; this version posted June 21, 2021. The copyright holder for this preprint (which was not certified by peer review) is the author/funder, who has granted medRxiv a license to display the preprint in perpetuity.

It is made available under a CC-BY-NC-ND 4.0 International license .

We then examined the number of publications retrieved from PubMed using the topmost 243 similar pairs of diseases from distinct categories as queries (see Methods section; Fig. 3). The 244 goal was to find out whether the gene-sharing similarities between diseases from different 245 categories detected in our networks could also be captured from direct co-occurrence in the general peer-reviewed literature over the 30-year period. For each disease pair, we obtained a

247 ratio between the similarity score of the diseases (i.e., the significance of the gene sharing 248 between them) and the total number of studies retrieved from PubMed that mention both 249 diseases of the pairs together (Table S4). This similarity-to-paper ratio was used to detect potentially understudied pairs of diseases that significantly share genes. Low similarity-to-paper ratio values (Figs. $3 \mathrm{~A}$ and $3 \mathrm{~B}$, light green, and Table S4) represent similar diseases with many papers already published about them or dissimilar disease pairs. An example of such a pair is fibromyalgia and depression. These diseases have significant gene sharing and also hundreds of scientific papers that explore their relationship in the literature (Fig. 3B). Conversely, the genetic association between osteoporosis and mycobacterial infection is low and so is the number of papers that investigate these diseases together (Fig. 3B). These cases were 257 considered as examples of a low knowledge gap between the genetic similarity obtained from 258 our network analysis and the established literature coverage of the disease pairs. 
medRxiv preprint doi: https://doi.org/10.1101/2021.06.16.21259049; this version posted June 21, 2021. The copyright holder for this preprint (which was not certified by peer review) is the author/funder, who has granted medRxiv a license to display the preprint in perpetuity.

It is made available under a CC-BY-NC-ND 4.0 International license .

A
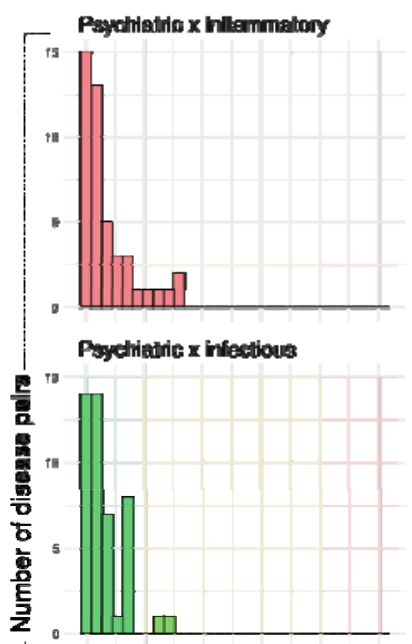

Inflammatory $x$ infectious

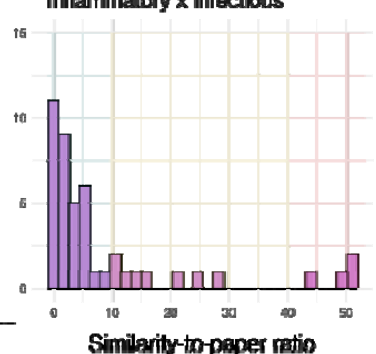

259

260

261

262

263

264

265

266

267

268
B
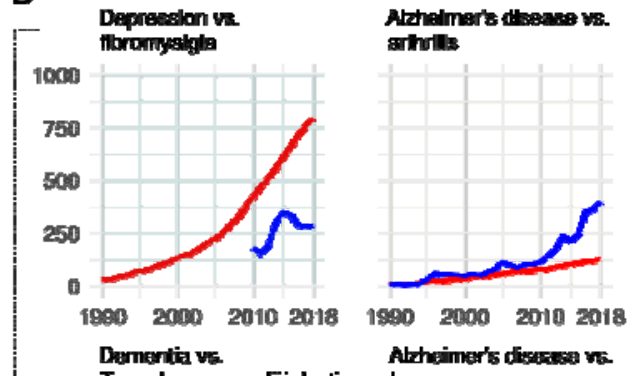

1000

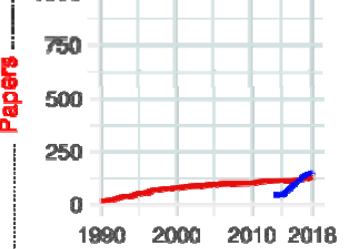

herpes

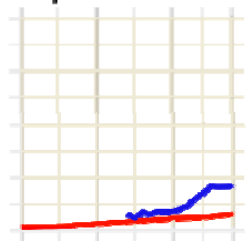

$1990 \quad 2000 \quad 20102018$

Arthritis vs.

hepatifis B

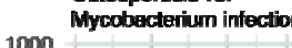

1000
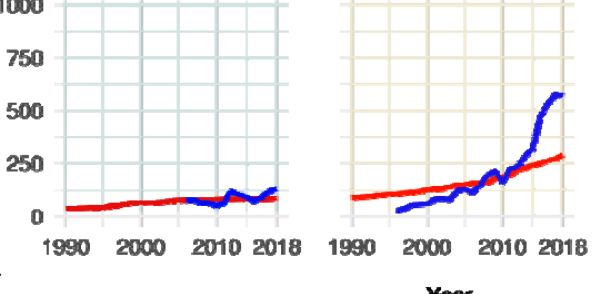

Year

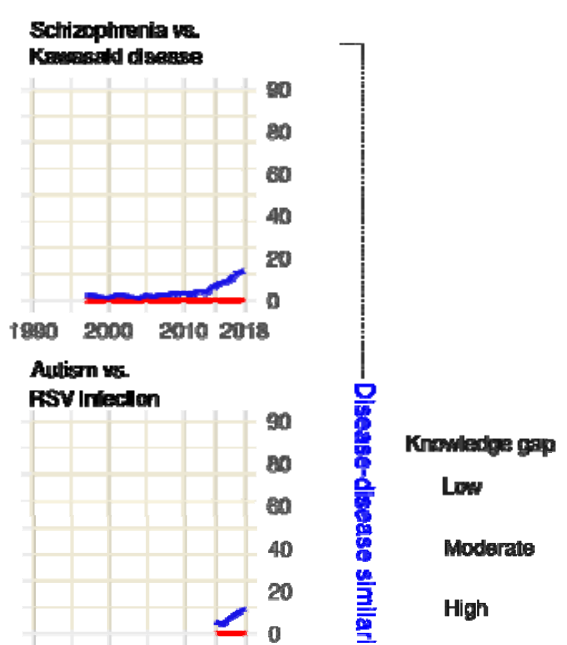

1990200020102018

Psoriasis vs.

melaria

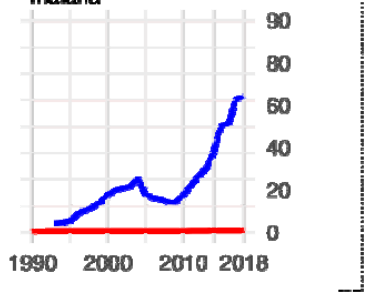

edge gap

Low

High

Figure 3. Evolution of the knowledge gap between diseases of different categories. A.

Number of disease pairs according to the similarity-to-paper ratio index. This index was obtained as a ratio of the similarity score to the total number of papers published for each disease pair in 2018. Low similarity-to-paper ratio $(<10)$ is colored in blue; intermediate similarity-to-paper ratio $(10<$ ratio $<40)$ is colored in yellow; and high similarity-to-paper ratio $(>40)$ is colored in pink. B. Selected cases of disease pairs with low, intermediate, or high similarity-to-paper ratios depicting the evolution in the number of papers on each pair and the evolution of the similarity between them. 
medRxiv preprint doi: https://doi.org/10.1101/2021.06.16.21259049; this version posted June 21, 2021. The copyright holder for this preprint (which was not certified by peer review) is the author/funder, who has granted medRxiv a license to display the preprint in perpetuity.

It is made available under a CC-BY-NC-ND 4.0 International license . S4) were considered as cases of moderate knowledge gap (Fig. 3A), which was the case for 272 arthritis and hepatitis B (Fig. 3B). As previously mentioned, several recent studies have explored the association between viral infections and autoimmune diseases (Dalakas, 2020; 274 Getts et al., 2013; Li et al., 2018). In 2018, there were over 250 published papers in which 275 arthritis and hepatitis B were mentioned together (Fig. 3B). Virally mediated arthritis represents $276 \sim 1 \%$ of all arthritis cases, including cases related to hepatitis B infection (Marks and Marks, 277 2016). Scientists have detected the hepatitis B virus in the synovial fluid of rheumatological 278 patients, which could contribute to the pathogenesis of arthritis (Chen et al., 2018). Although 279 these diseases are known to be clinically associated at least since the 1970s (Mirise and 280 Kitridou, 1979), our results show that the knowledge on the gene sharing between them 281 increased rapidly after 2015 , which was not followed at the same rate by the number of papers 282 published on the two diseases together. This represents a potential gap to be explored by novel 283 research on the genetic bases of the relationship between arthritis and hepatitis B.

284 Lastly, we considered the disease pairs with strong gene sharing and few studies 285 supporting a direct association as cases of a high knowledge gap (Figs. 3A and 3B, pink, and 286 Table S4). We suggest that these cases might represent potentially underexplored fields of 287 research that deserve further investigation. Surprisingly, the number of papers published until 2882018 that mentioned psoriasis and malaria together was neglectable (Fig. 3B). These diseases 289 share 31 genes, one-third of the genes associated with psoriasis, and over $10 \%$ of the genes 290 associated with malaria in the 2018 network. Hydroxychloroquine, a drug used to treat malaria 291 (Ben-Zvi et al., 2012) and rheumatic diseases, such as arthritis and lupus (Ben-Zvi et al., 2012), 
medRxiv preprint doi: https://doi.org/10.1101/2021.06.16.21259049; this version posted June 21, 2021. The copyright holder for this preprint (which was not certified by peer review) is the author/funder, who has granted medRxiv a license to display the preprint in perpetuity.

It is made available under a CC-BY-NC-ND 4.0 International license .

292 can trigger psoriatic lesions (Balak and Hajdarbegovic, 2017). Among a few papers in which 293 malaria and psoriasis are mentioned together, there is a report from 2014 that describes cases 294 of hydroxychloroquine-induced psoriasis in patients undergoing malaria treatment (Gravani et 295 al., 2014). The authors of this study suggest that there should be guidelines for the 296 management of psoriasis patients who are also at risk of malaria (Gravani et al., 2014). Our 297 findings corroborate the need for future studies to investigate the association between these 298 diseases.

299

300

\section{Evolution of biological pathways}

301

We performed a gene overrepresentation analysis (ORA) against Reactome pathways

with the genes associated with the top 9 most connected diseases in each year from 1990 to 2018 (Figs. 4-6 and Table S5). We detected 433 Reactome pathways that presented significant enrichment (p.adjust $<0.01$ ) among the genes of at least one disease (Table S5). Functional enrichment analysis, such as ORA, often yields too many significant pathways, making these results difficult to interpret at the individual pathway level. For this reason, we used a network approach to reduce the complexity of the obtained set of enriched pathways (see Methods section). Briefly, we built a pathway network (Fig. 4) with the significant Reactome pathways obtained from the ORA. We connected these pathways to each other according to the gene 310 sharing between them, similar to what was done in Fig. $1 \mathrm{~A}$. We then identified 11 clusters of 311 closely connected pathways in the network and annotated these clusters according to the main 312 biological functions of the pathways within them (Fig. 4 and Table S5). One of the detected 313 clusters grouped several pathways associated with interferon-stimulated genes, interleukins, 314 and antigen presentation (Fig. 4 and Table S5). The pathways in this cluster were significantly 
medRxiv preprint doi: https://doi.org/10.1101/2021.06.16.21259049; this version posted June 21, 2021. The copyright holder for this preprint (which was not certified by peer review) is the author/funder, who has granted medRxiv a license to display the preprint in perpetuity. It is made available under a CC-BY-NC-ND 4.0 International license.

315 enriched among the genes of diseases in all categories, including malaria, HIV infection, 316 arthritis, lupus, depression, and Alzheimer's disease (Fig. 5). The pathways related to 317 interleukin signaling (e.g., "interleukin 10 signaling"), for instance, were among the top enriched 318 pathways associated with depression genes in the 2018 network (Fig. 5 and Table S5). Another 319 cluster of pathways that showed consistent enrichment across all disease categories was NFKB320 mediated inflammation induced by toll-like receptors (TLRs), T-cell receptors (TCRs), and B-cell 321 receptors (BCRs; Fig. 4). These results illustrate the most recurring theme detected in our 322 study: psychiatric, inflammatory, and infectious diseases share common immunological mechanisms that are mostly related to innate immunity and inflammation. 
medRxiv preprint doi: https://doi.org/10.1101/2021.06.16.21259049; this version posted June 21, 2021. The copyright holder for this preprint (which was not certified by peer review) is the author/funder, who has granted medRxiv a license to display the preprint in perpetuity.

It is made available under a CC-BY-NC-ND 4.0 International license .

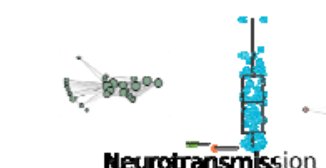

Urfolded protein response (UPR)

Figure 4. Reactome term network built from the ORA results of the genes associated with

human diseases in 2018. Significant Reactome ORA terms (p.adjust < 0.01) obtained from the genes of the top 9 diseases in the 2018 network were connected to each other according to the significance of the gene sharing between them (edge weight). Only terms with a gene sharing with a p.adjust $<0.01$ were connected. We detected 11 clusters (node colors) of closely related terms using the Louvain clustering algorithm in the R package igraph (Csardi and Nepusz, 2006) and compared the enrichment score distribution of the terms in these clusters in each disease category (box plots). Box plots are colored according to the disease categories: green infectious diseases, orange - inflammatory diseases, and light blue - psychiatric disorders. Dots 
medRxiv preprint doi: https://doi.org/10.1101/2021.06.16.21259049; this version posted June 21, 2021. The copyright holder for this preprint (which was not certified by peer review) is the author/funder, who has granted medRxiv a license to display the preprint in perpetuity.

It is made available under a CC-BY-NC-ND 4.0 International license .

334 in the box plots represent individual enriched Reactome pathways that belong to each network

335 cluster.

336

337

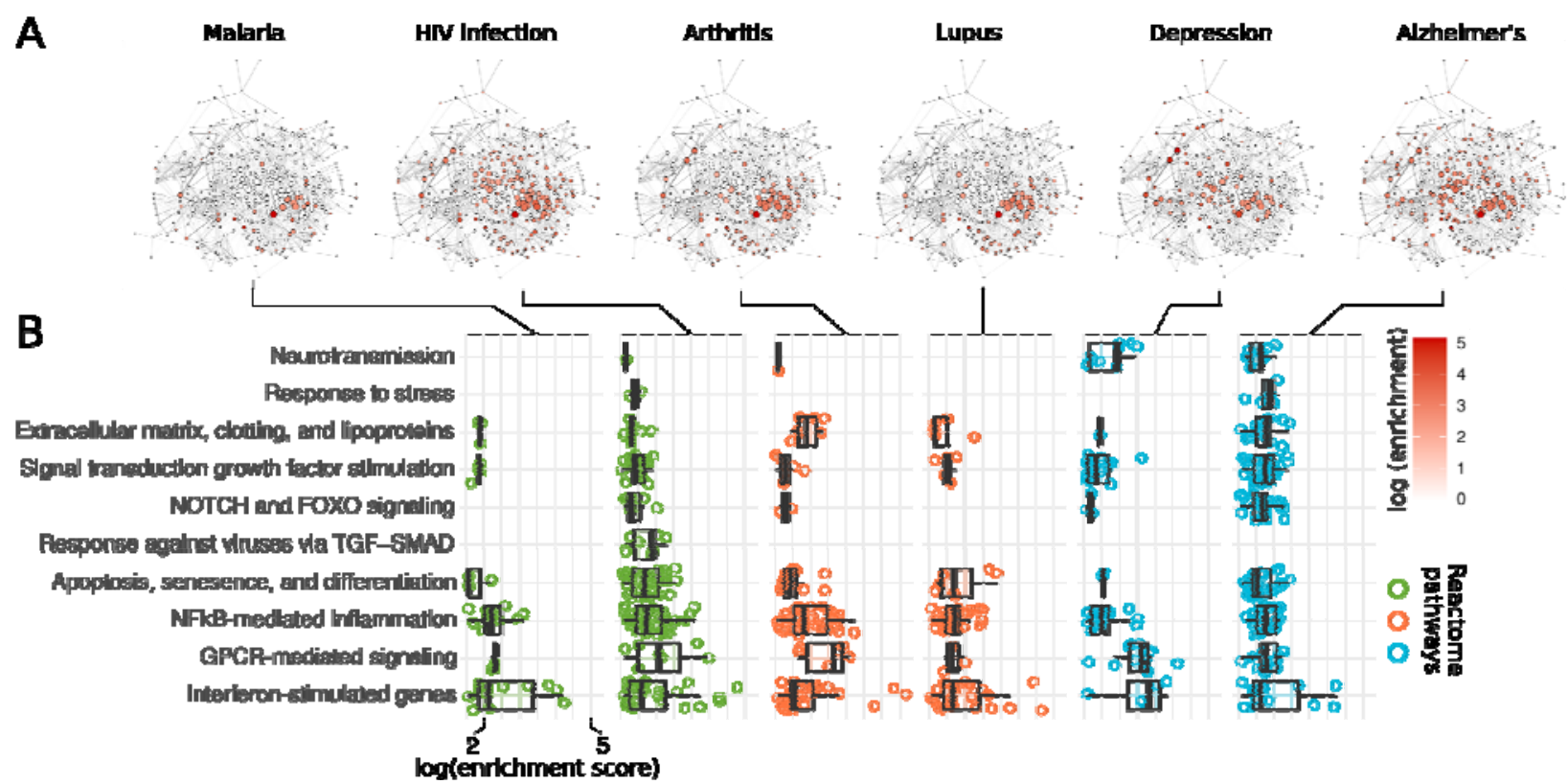

338

339 Figure 5. Key biological pathways are enriched among the genes associated with human

340 diseases in 2018. A. ORA networks depicting the enrichment score of Reactome pathways in

341 selected infectious, inflammatory and psychiatric disorders. The networks in A have the same

342 topology of the network in Figure 04 . The nodes are colored according to the logarithm of

343 enrichment score $\left(-\log _{10} \mathrm{pval}\right)$ of the terms represented by each node. B. ORA enrichment score

344 distribution of the terms in the clusters and diseases from panel A. Box plots are colored

345 according to the category of each disease: green - infectious, orange - inflammatory, and light 
medRxiv preprint doi: https://doi.org/10.1101/2021.06.16.21259049; this version posted June 21, 2021. The copyright holder for this preprint (which was not certified by peer review) is the author/funder, who has granted medRxiv a license to display the preprint in perpetuity.

It is made available under a CC-BY-NC-ND 4.0 International license .

346 blue - psychiatric. Dots in the box plots represent individual Reactome pathways that belong to

347 the clusters listed in the y axis and that were enriched in each disease.

348

349

Conversely, we found a cluster of closely connected pathways related to

350 neurotransmission that were enriched mostly among the genes of psychiatric disorders (Fig. 4

351 and Table S5). However, three inflammatory and infectious diseases (hepatitis B, arthritis, and

352 HIV infection) presented enrichment for pathways in this cluster (Fig. 5 and Fig. S5). The genes

353 related to these diseases presented enrichment for the pathway "transcriptional regulation

354 MECP2", a member of the neurotransmission cluster. Methyl CpG binding protein 2 (MECP2) is

355 located in the $\mathrm{X}$ chromosome, and mutations in this gene are the primary cause of Rett

356 syndrome (Liyanage and Rastegar, 2014). There is no evidence in the scientific literature that

357 there is a link between HIV infection or hepatitis B and Rett syndrome, but recent studies

358 indicate a link between this neurodevelopmental disorder and autoimmune diseases, including

359 arthritis (De Felice et al., 2016). Moreover, AIDS patients can develop neurological

360 manifestations similar to those observed in Rett patients, such as cognitive dysfunction and

361 movement disorders (Brew and Garber, 2018). Our results suggest that the similarity between

362 Rett syndrome and autoimmune diseases might also occur for infectious diseases of viral 363 etiology. 
medRxiv preprint doi: https://doi.org/10.1101/2021.06.16.21259049; this version posted June 21, 2021. The copyright holder for this preprint (which was not certified by peer review) is the author/funder, who has granted medRxiv a license to display the preprint in perpetuity.

It is made available under a CC-BY-NC-ND 4.0 International license .

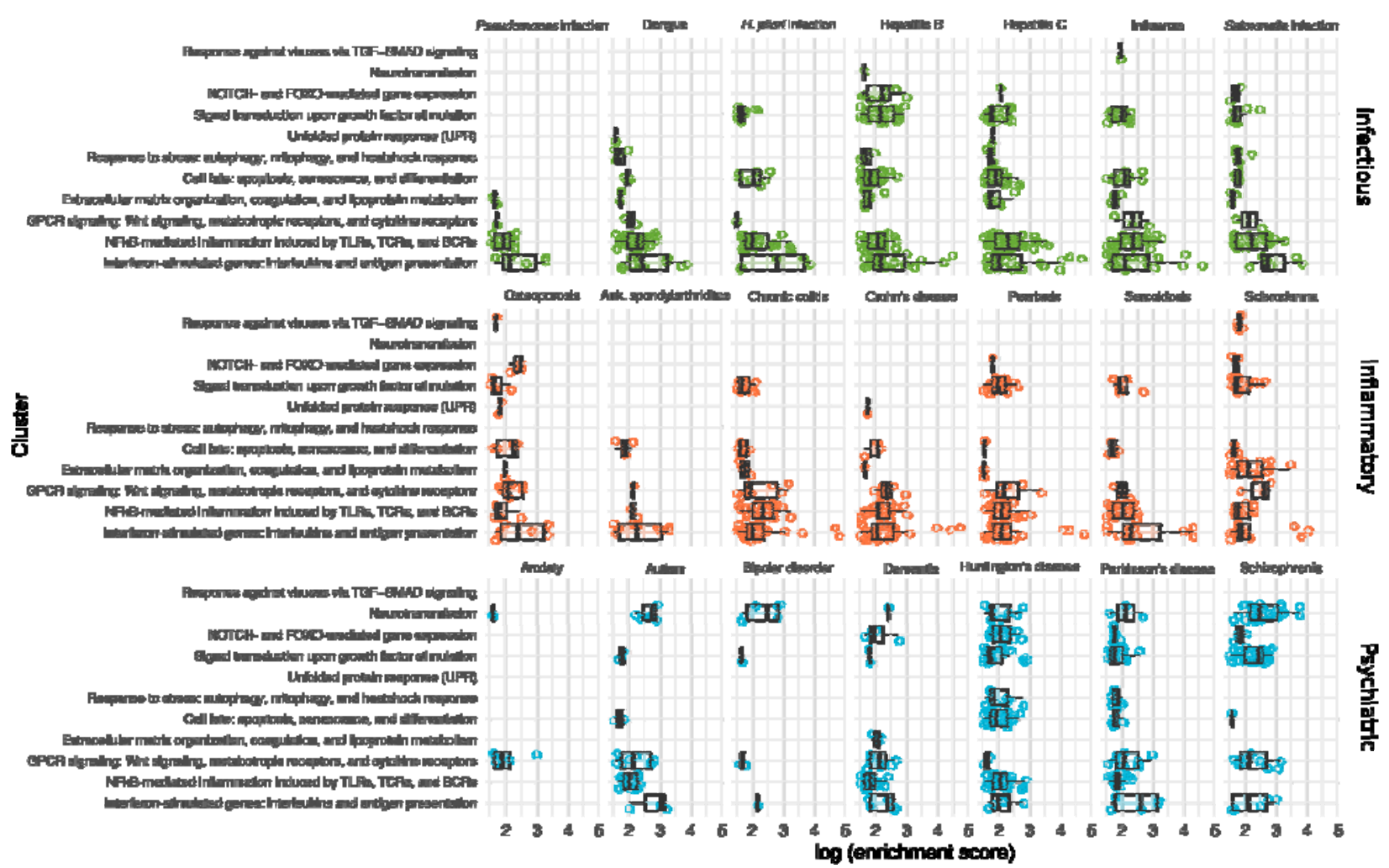

Figure S5. ORA network analysis of genes associated with inflammatory, infectious, and

psychiatric diseases. Enrichment score distribution of the terms in the clusters from Fig. 4 for

diseases not depicted in Fig. 5. Box plots illustrate the distribution of the enrichment scores of

the Reactome pathways in each cluster. diseases of different categories (Fig. 4). The genes related to arthritis and those related to Alzheimer's disease presented enrichment for pathways related to the extracellular matrix organization, coagulation, and lipoprotein metabolism (Fig. 5). In arthritis, fibroblast-like 374 synoviocytes become hyper-inflammatory and disrupt the extracellular matrix integrity, which 375 leads to the degradation of synovial joint collagen (Nygaard and Firestein, 2020). In Alzheimer's 
medRxiv preprint doi: https://doi.org/10.1101/2021.06.16.21259049; this version posted June 21, 2021. The copyright holder for this preprint (which was not certified by peer review) is the author/funder, who has granted medRxiv a license to display the preprint in perpetuity.

It is made available under a CC-BY-NC-ND 4.0 International license .

376 disease, some extracellular matrix macromolecules seem to promote the production and 377 stabilization of amyloid $\beta$, while others act to protect neurons from amyloidosis (Sethi and Zaia, 378 2017). The pathways in the signal transduction on growth factor stimulation and GPCR379 mediated signaling clusters were also enriched among the genes of diseases in all categories 380 (Figs. 4, 5, and S5). This result was expected because the genes involved in signal transduction 381 and intracellular signaling are usually shared between cellular pathways and are involved in 382 virtually all biological functions relevant to diseases (Figs. 5 and S5). After determining the major biological functions related to the genes connected to 384 infectious, inflammatory, and psychiatric diseases in the 2018 network, we investigated how this 385 knowledge evolved from 1990 to 2018 (Fig. 6). The pathways related to interferon-stimulated 386 genes, interleukins, and antigen presentation became enriched for the genes associated with 387 inflammatory and infectious diseases already since the early 1990s (Fig. 6). Surprisingly, this 388 enrichment appeared earlier for inflammatory diseases, despite the highly relevant role of 389 interferon-stimulated genes and antigen presentation in infectious diseases. Conversely, there 390 was a significant increase in the enrichment of these pathways for the genes related to 391 depression, autism, and schizophrenia since 2010 (Fig. 6). Recently, the specific roles of the 392 immune system in psychiatric diseases begun to be revealed (Chen et al., 2016; de Baumont et 393 al., 2015; Dong et al., 2018; Madore et al., 2016; Yuan et al., 2019). Particularly, neuroglial cells 394 have gained importance as key neuroimmune players in the development of autism (microglia 395 and oligodendrocytes; Scuderi and Verkhratsky, 2020), Alzheimer's disease (microglia; Clayton 396 et al., 2017), and schizophrenia (astrocytes; Gandal et al., 2018). The association of pathways 397 related to apoptosis, senescence, and cell differentiation with psychiatric disorders has also 398 occurred recently, except with Alzheimer's disease, which began early in the period (Fig. 6). 
medRxiv preprint doi: https://doi.org/10.1101/2021.06.16.21259049; this version posted June 21, 2021. The copyright holder for this preprint (which was not certified by peer review) is the author/funder, who has granted medRxiv a license to display the preprint in perpetuity.

It is made available under a CC-BY-NC-ND 4.0 International license .

399 Alzheimer's, Parkinson's, and Huntington's diseases are neurodegenerative conditions in which 400 chronic neuronal death happens in distinct parts of the brain (Dugger and Dickson, 2017). We 401 also found an increasing association in recent years of genes related to autism and depression 402 to cell fate pathways (Fig. 6), showing that these disorders might also have a neurodegenerative 403 component. In fact, apoptosis and cell death in response to stress and inflammation are relevant 404 factors in the pathogenesis of autism (D. Dong et al., 2018) and depression (Leonard, 2018). 

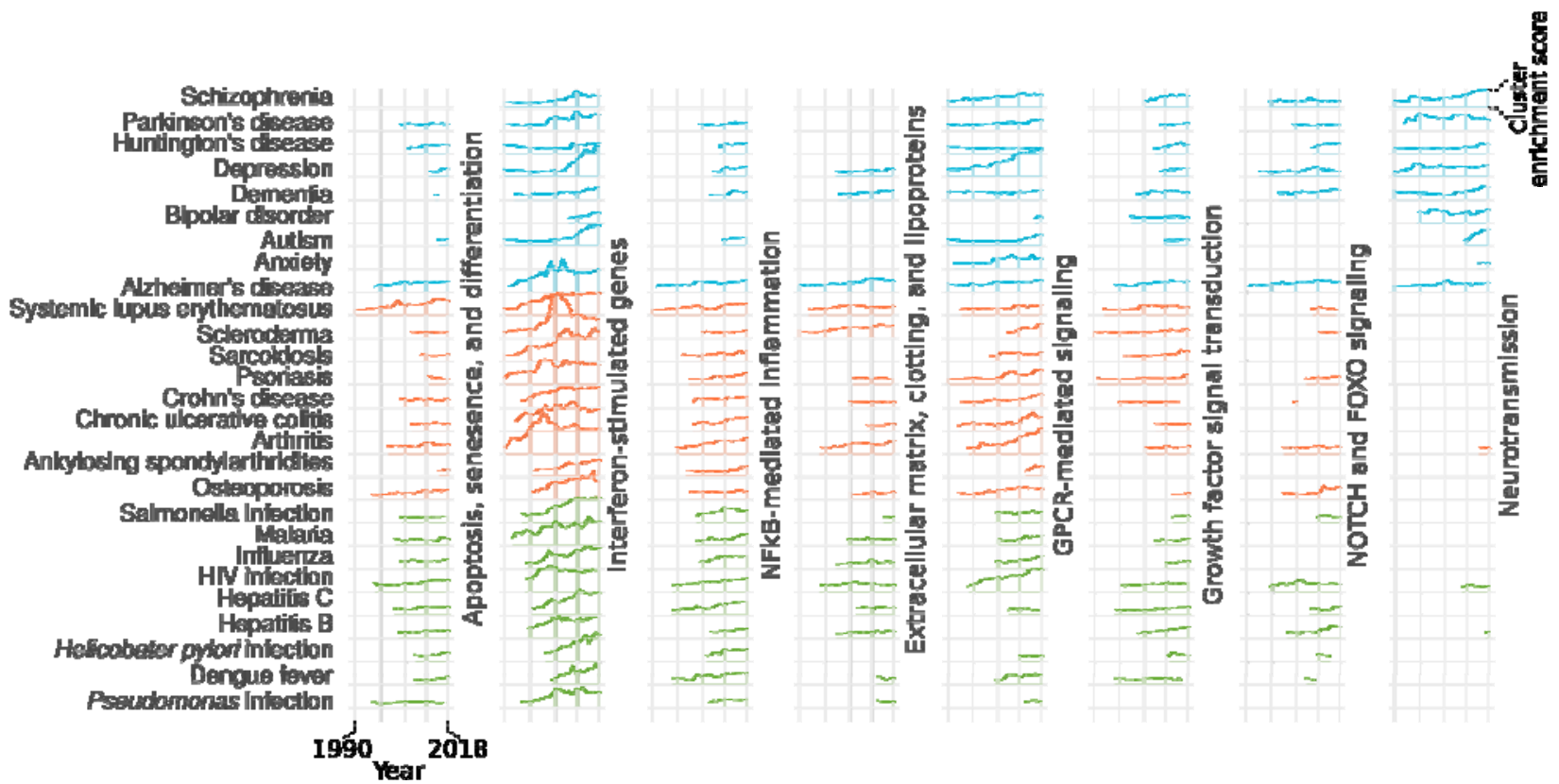

score of selected clusters from the network in Figure 04 for the top 9 diseases in each category

from 1990 to 2018 . The height of the ridges are proportional to the mean enrichment score

408 (mean $\log _{10}$ pval) of the Reactome pathways in each cluster listed in the y axis.

409

\section{Evolution of drug target hub genes}

Lastly, we examined how drugs that are used to treat inflammatory, infectious, and

412 psychiatric diseases target the genes that are shared between the three categories. We found

413 that 345 genes were common to all disease categories (Fig. 7A). Ninety-nine genes were

414 shared only between inflammatory and psychiatric diseases; 259 were common only between

415 psychiatric and infectious diseases; and a total of 409 genes were related exclusively to

416 inflammatory and infectious diseases (Fig. 7A). The remaining genes were unique to

417 inflammatory (493 genes), psychiatric (869 genes), and infectious diseases (1,209 genes; Fig.

418 7A). 
medRxiv preprint doi: https://doi.org/10.1101/2021.06.16.21259049; this version posted June 21, 2021. The copyright holder for this preprint (which was not certified by peer review) is the author/funder, who has granted medRxiv a license to display the preprint in perpetuity.

A

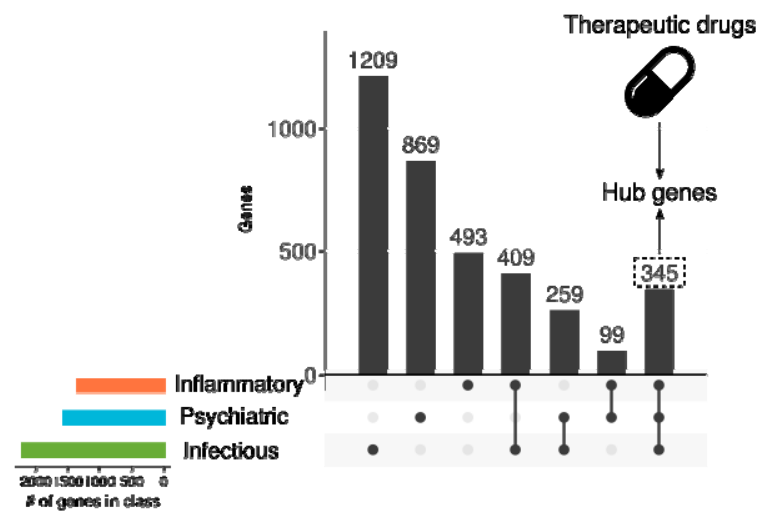

C

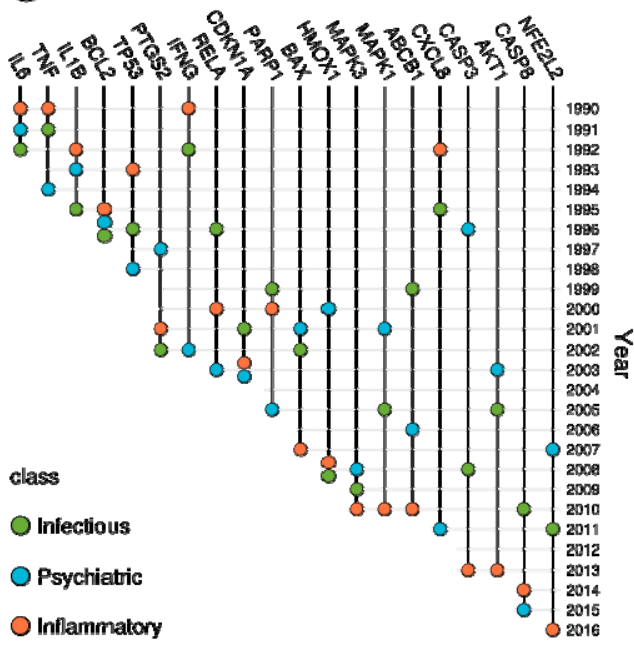

D
B
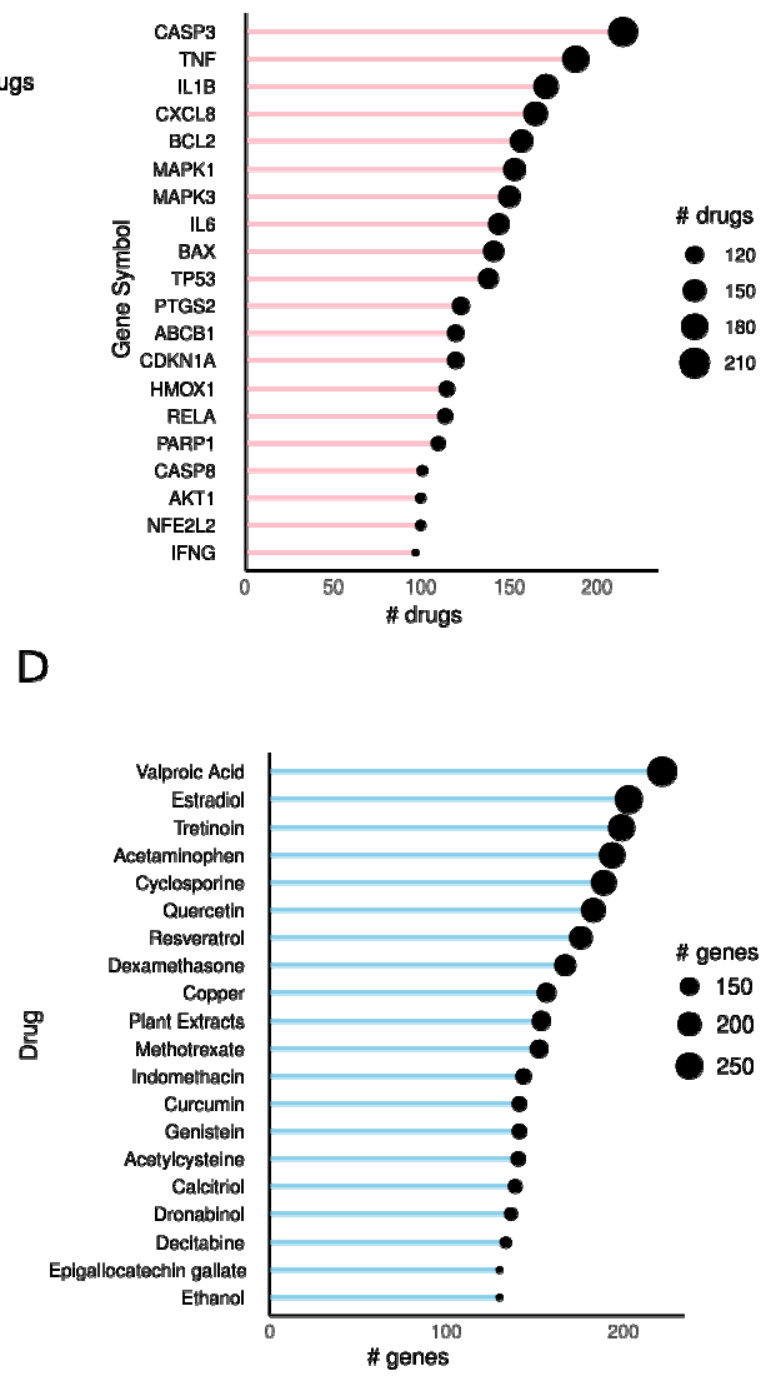

E

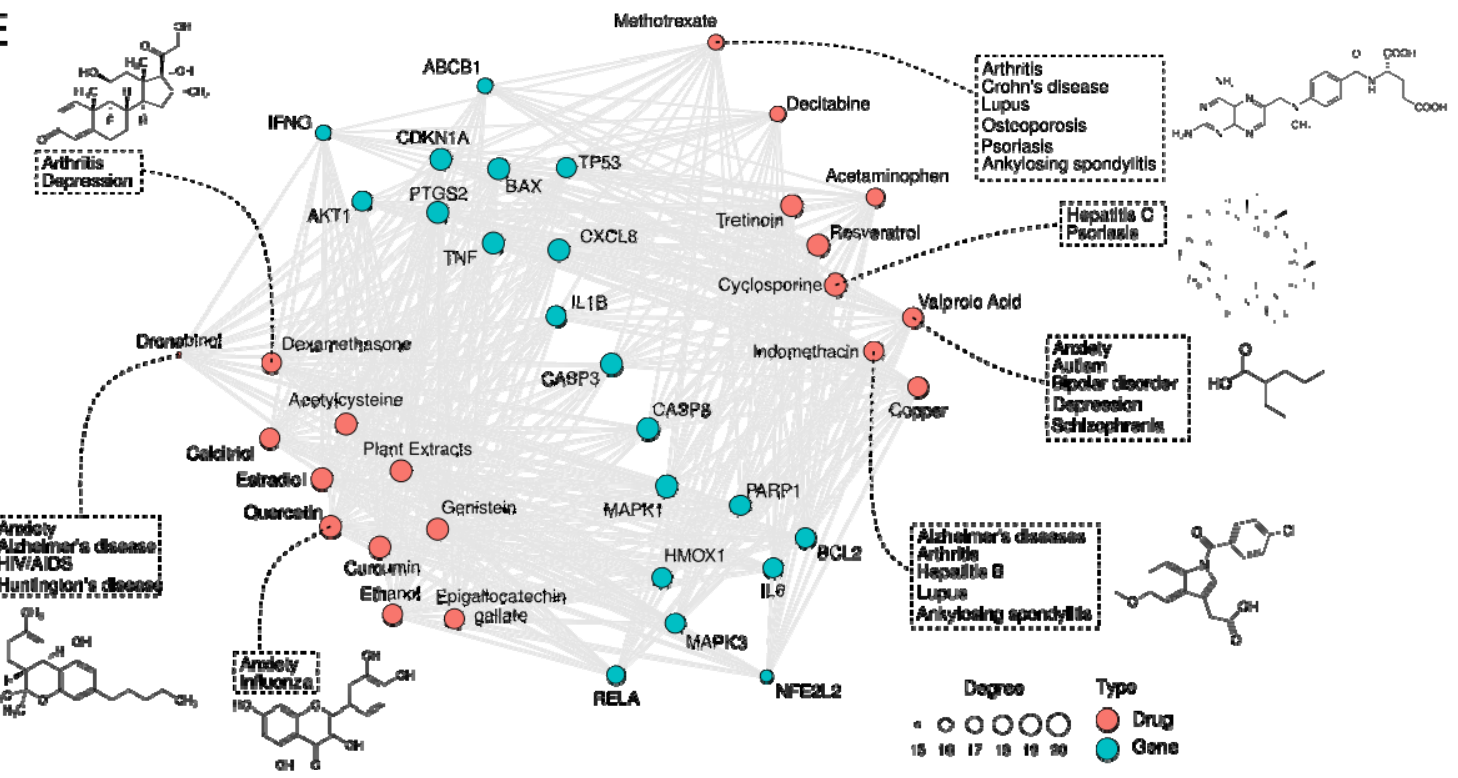


medRxiv preprint doi: https://doi.org/10.1101/2021.06.16.21259049; this version posted June 21, 2021. The copyright holder for this preprint (which was not certified by peer review) is the author/funder, who has granted medRxiv a license to display the preprint in perpetuity.

It is made available under a CC-BY-NC-ND 4.0 International license .

420 Figure 7. Evolution of drug target hub genes. A. UpSet plot showing the common genes

421 between all categories (hub genes), between two categories exclusively and genes that are

422 unique to each category. B. Number of therapeutic drugs of inflammatory, infectious, and

423 psychiatric diseases that target the top 20 target hub genes according to the comparative

424 toxicogenomics database (CTD). C. Timeline of the association of the top 20 target hub genes

425 to the gene-disease network. The year in which each gene was associated with the first disease

426 of each category is depicted by the circles with distinct colors for each category. D. Number of

427 hub genes targeted by the top 20 drugs that target more hubs according to CTD. E. Drug-gene

428 network depicting the top 20 drugs and that target hub genes. We selected a few drugs and

429 illustrated their molecular structure and diseases for which they are listed as therapeutic

430 according to CTD.

431

432 We used the comparative toxicogenomics database (CTD; Davis et al., 2021) to find 433 drugs that have a therapeutic relationship with the top 9 diseases and the list of genes that 434 these drugs affect (see Methods section). From these lists, we highlight the top 20 most 435 common target genes of the therapeutic drugs listed by CTD (Fig. 7B). Among these genes, IL6, 436 TNF, and interferon gamma (IFNG) were already connected to inflammatory diseases in the 4371990 network and were gradually related to diseases in the other two categories until 2002 (Fig. 438 7C). Interleukin 1 beta (IL1B), B-cell lymphoma 2 (BCL2), tumor protein P53 (TP53), and 439 CXCL8 also appeared in our networks in the early 1990s and were first connected to 440 inflammatory diseases (Fig. 7C). Eight drug target genes were first connected to psychiatric 441 disorders (Fig. 7C): caspase 3 (CASP3; 1996), prostaglandin-endoperoxide synthase 2 442 (PTGS2; 1997), heme oxygenase 1 (HMOX1; 2000), BCL-2-associated X (BAX) and mitogen- 
medRxiv preprint doi: https://doi.org/10.1101/2021.06.16.21259049; this version posted June 21, 2021. The copyright holder for this preprint (which was not certified by peer review) is the author/funder, who has granted medRxiv a license to display the preprint in perpetuity.

443 activated protein kinase 1 (MAPK1; 2001), RAC-alpha serine/threonine-protein kinase (AKT1;

444 2003), nuclear factor erythroid 2-related factor 2 (NFE2L2; 2007), and mitogen-activated protein

445 kinase 1 (MAPK3; 2008). The other 5 genes were first connected to infectious diseases (Fig.

446 7C): NFkB P65 Subunit (RELA; 1996), poly(ADP-Ribose) polymerase 1 (PARP1) and ATP

447 binding cassette subfamily $B$ member 1 (ABCB1; 1999), cyclin dependent kinase inhibitor 1A

448 (CDKN1A; 2001), and caspase 8 (CASP8; 2010). All top 20 drug target genes were first

449 connected to one of the categories until 2010, with the majority of new connections happening

450 in the 1990s (Fig. 7C). These are very well-known genes involved in inflammation (e.g., IL6 and

451 IL1B), innate immunity (e.g., IFNG), apoptosis (e.g., CASP3 and CASP8), cell cycle (e.g.,

452 TP53), and other key biological functions that are altered in several diseases.

453 Next, we found the top 20 therapeutic drugs that affect the most hub genes of

454 inflammatory, psychiatric, and infectious diseases (Fig. 7D). Valproic acid, a class I histone

455 deacetylase (HDAC) inhibitor (Göttlicher et al., 2001), was the drug that affected the most hub

456 genes, 259 (Fig. 7D). According to CTD, among the diseases we analyzed in this study, valproic

457 acid is a therapeutic drug for anxiety, autism, bipolar disorder, and schizophrenia (Fig. 7E). This

458 drug is also an efficient anti-convulsant used to treat epilepsy (Tomson et al., 2016) because it

459 facilitates gamma-aminobutyric acid (GABAergic) neurotransmission (Chateauvieux et al., 460 2010). There is extensive evidence in the literature of the anti-inflammatory effects of valproic 461 acid and its potential use to treat conditions such as spinal cord injury (S. Chen et al., 2018), 462 renal ischemia (Costalonga et al., 2016), and sepsis-induced heart failure (Shi et al., 2019).

463 Valproate was also speculated as a potential repurposing candidate to treat diseases caused by 464 infectious agents, such as COVID-19 (Pitt et al., 2021) and toxoplasmosis (Goodwin et al., 465 2008). HDAC inhibitors promote epigenetic modifications in the genome that induce the 
medRxiv preprint doi: https://doi.org/10.1101/2021.06.16.21259049; this version posted June 21, 2021. The copyright holder for this preprint (which was not certified by peer review) is the author/funder, who has granted medRxiv a license to display the preprint in perpetuity.

It is made available under a CC-BY-NC-ND 4.0 International license .

466 expression of genes in many biological functions and cell types (Hull et al., 2016). This could 467 explain valproic acid's versatility and why it ranked first in our analysis.

468 Among the other top 20 drugs, we found molecules that are currently under investigation 469 for repositioning from one disease category to another. Methotrexate (Fig. 7D), which affects 470141 genes among the 345 hubs, is used to treat several inflammatory diseases, including 471 psoriasis, lupus, and arthritis (Fig. 7E). Recently, a randomized clinical trial revealed a potential 472 for methotrexate to treat positive symptoms in schizophrenia patients (Chaudhry et al., 2020). 473 The authors of the trial argue that this effect of methotrexate might be achieved through 474 resetting of systemic regulatory T-cell control of immune signaling, which is also the way this 475 drug is thought to act in autoimmune diseases (Chaudhry et al., 2020). The use of anti476 inflammatory drugs for the treatment of neuropsychiatric diseases gained traction in recent 477 years (Kohler et al., 2016; Ozben and Ozben, 2019; Pandurangi and Buckley, 2020; Rosenblat 478 et al., 2016) influenced by the increasing evidence that these disorders have underlying immune 479 causes, which we have extensively demonstrated in this study. Dexamethasone (Fig. 7D) is a 480 glucocorticoid anti-inflammatory drug listed in CTD as a therapy for arthritis and depression (Fig. 481 7E), but it is also used to treat several other inflammatory disorders. Indeed, dexamethasone 482 was one of the few drugs submitted to randomized clinical trials that reduced mortality in 483 COVID-19 patients subjected to invasive ventilation (RECOVERY Collaborative Group, 2021). 484 Several of the other top 20 drugs were also listed in CTD to be used as therapy for diseases of 485 different categories, such as cyclosporine (hepatitis C and psoriasis), indomethacin (Alzheimer's 486 and autoimmune diseases), dronabinol (neuropsychiatric diseases and HIV infection), and 487 quercetin (anxiety and influenza; Fig. 7E). 
medRxiv preprint doi: https://doi.org/10.1101/2021.06.16.21259049; this version posted June 21, 2021. The copyright holder for this preprint (which was not certified by peer review) is the author/funder, who has granted medRxiv a license to display the preprint in perpetuity.

It is made available under a CC-BY-NC-ND 4.0 International license .

489

490

49

492

493

494

495

496

497

498

499

500

501

502

503

50 505 506

507

508

509

510

511

\section{Discussion}

Similar to the exponential increase in the number of published papers seen in the past decades (Fortunato et al., 2018), the number of genes associated with psychiatric, inflammatory, and infectious diseases have also increased significantly in the past 30 years . This rapid growth in knowledge about the genetic underpinnings of these diseases can be directly attributed to at least two historical landmarks: the publication of the human genome in 2001 (Lander et al., 2001; Venter et al., 2001) and the advent of high-throughput DNAsequencing technologies (Margulies et al., 2005). Discrete advances in genes associated with specific diseases could also be spotted throughout the period analyzed here. In 1996, the triple therapy for HIV was developed using nucleoside reverse-transcriptase inhibitors and protease inhibitors (Hammer et al., 1996). In the same year, $50 \%$ of the new genes added to the knowledge network were connected to HIV infection. In 2005, a peak of novel genes associated with psoriasis and systemic lupus erythematosus was detected. This year also saw the discovery of the $\mathrm{Th}_{17}$ cell lineage (Langrish et al., 2005). The central role of these proinflammatory cells in the pathogenesis of autoimmune and infectious diseases was later identified (Zambrano-Zaragoza et al., 2014). Indeed, the key genes of the differentiation and maintenance of the $\mathrm{Th}_{17}$ phenotype in $\mathrm{CD}^{+} \mathrm{T}$ lymphocytes, such as interleukin 17F (IL17F), interleukin 21 (IL21), the peroxisome proliferator-activated receptor gamma (PPARG), and the fatty acid-binding protein 5 (FABP5), were connected to psoriasis and systemic lupus erythematosus in the network in 2005 (Hwang, 2010; Nalbant and Eskier, 2016). One of the advantages of using text mining and network medicine to study the relationships between genes and diseases is the possibility of detecting novel connections from established scientific knowledge. When two diseases share a genetic mechanism, they can also 
medRxiv preprint doi: https://doi.org/10.1101/2021.06.16.21259049; this version posted June 21, 2021. The copyright holder for this preprint (which was not certified by peer review) is the author/funder, who has granted medRxiv a license to display the preprint in perpetuity.

It is made available under a CC-BY-NC-ND 4.0 International license .

512 present common clinical or epidemiological characteristics, despite having distinct etiological

513 backgrounds (Barabási et al., 2011). These similarities can inform researchers of potential

514 treatment options (Lüscher Dias et al., 2020). Here, we showed that diseases from

515 inflammatory, psychiatric, and infectious etiologies significantly share genes with each other.

516 This sharing was strong between disease pairs that were well studied together, such as

517 depression and fibromyalgia. Conversely, the gene sharing between psoriasis and malaria could

518 be perceived in our knowledge networks since the 2000 s, but the number of papers featuring

519 the two conditions together in PubMed is virtually null. We detected a few such cases, mostly

520 involving neglected infectious diseases, which could explain the knowledge gap. We also found

521 cases of diseases that just recently began to share genes that also lack many publications

522 directly connecting them in the literature. A case in point is autism and RSV. We also found

523 disease pairs, such as dementia and Toxoplasma gondii infection, for which there have been

524 direct associations in the literature since 1990, but that just recently started to share genes in

525 the network. Our results reveal potentially underexplored pathways for future research on the

526 association between diseases of distinct categories and also for the discovery of new genes

527 related to well-studied disease pairs.

528 The sharing of genes between diseases from distinct categories also reflects in the 529 overlap of biological functions, particularly those related to immunological processes. The genes

530 of several diseases in all categories presented enrichment for Reactome pathways related to 531 the interferon response, cytokines, and NFkB-mediated inflammation. This pattern was 532 detectable in our networks since the early 1990s for inflammatory diseases and gradually 533 appeared for infectious and psychiatric diseases as well. Pathways associated with 534 neurotransmission were almost exclusively enriched among the genes of psychiatric diseases. 
medRxiv preprint doi: https://doi.org/10.1101/2021.06.16.21259049; this version posted June 21, 2021. The copyright holder for this preprint (which was not certified by peer review) is the author/funder, who has granted medRxiv a license to display the preprint in perpetuity.

It is made available under a CC-BY-NC-ND 4.0 International license .

535 Nevertheless, we found enrichment for a neurotransmission-related pathway, "transcriptional

536 regulation by MECP2", among the genes of HIV infection and hepatitis B that could point to a

537 connection between these disorders and Rett syndrome, a neurological condition. Our

538 functional enrichment results also highlighted the relevance of core cellular functions in

539 diseases of all categories, such as signal transduction and the regulation of gene expression by

540 transcription factors.

$541 \quad$ Our network medicine text mining approach also revealed how shared genes between

542 disease categories can signal toward common therapeutic solutions. The findings presented in

543 the last section of our study emphasize the relevance of drugs that target shared genes for the

544 treatment of distinct diseases. Our results show that the genes targeted by therapeutic drugs

545 shared by inflammatory, psychiatric, and infectious diseases have been associated with these

546 disorders early in the past 30 years of scientific research. These genes are associated with

547 inflammation, the cell cycle, apoptosis, and central pathways of cellular function. We also

548 demonstrated that well-established and promising cases of repositioning involve drugs that

549 target shared genes between diseases. Future studies should aim to reveal more common

550 molecular mechanisms between these categories of diseases as well as to harness that

551 knowledge for novel drug discovery and repurposing.

552 In summary, we could apply a machine learning and cognitive computing text-mining

553 strategy using WDD to extract knowledge about genes related to inflammatory, infectious, and

554 psychiatric diseases from the scientific literature and depict how this knowledge evolved during

555 the past 30 years. 
medRxiv preprint doi: https://doi.org/10.1101/2021.06.16.21259049; this version posted June 21, 2021. The copyright holder for this preprint (which was not certified by peer review) is the author/funder, who has granted medRxiv a license to display the preprint in perpetuity.

It is made available under a CC-BY-NC-ND 4.0 International license .

\section{Methods}

\section{Knowledge network construction}

558 We built knowledge networks containing interactions between diseases and genes using

559 the WDD (Y. Chen et al., 2016). WDD discovers connections between genes and diseases

560 using a natural language processing algorithm that reads full texts from PMC open access

561 journals, patents, and abstracts in the MEDLINE (PubMed) database. A connection is found

562 when two terms of interest (e.g., genes and diseases) are detected in the same sentence,

563 separated by a preposition or a verb. These connections can be derived from many sources of

564 evidence, such as gene expression, disease-associated mutations, genome-wide association

565 studies, or protein expression experiments. WDD attributes a confidence score $(0-100 \%)$ to

566 each association based on the number of documents in which the relation is found and also on

567 the semantic relevance of the link, determined by the natural language processing algorithm.

568 We performed independent searches on WDD with 27 inflammatory diseases, 63

569 infectious diseases, and 9 psychiatric and neurological disorders (Table S1) in July 2018. WDD

570 returned lists of genes related to these diseases according to the scientific literature in each

571 year from 1990 to 2018 . These associations are cumulative, that is, the genes associated with

572 the diseases in 2018 include all the associations present in the previous year. We only kept

573 connections between genes and diseases supported by a confidence score of at least $50 \%$ and

5742 documents of evidence. Custom $\mathrm{R}$ code was used to process, filter, and analyze data and to 575 plot figures. The full code of all analyses and figures in this study is available at 576 https://github.com/csbl-usp/evolution_of_knowledge.

577

578 
medRxiv preprint doi: https://doi.org/10.1101/2021.06.16.21259049; this version posted June 21, 2021. The copyright holder for this preprint (which was not certified by peer review) is the author/funder, who has granted medRxiv a license to display the preprint in perpetuity.

\section{Evolution of knowledge}

580 We calculated Fisher's exact test $p$-value of the gene overlap between each pair of 581 diseases in each year from 1990 to 2018 . The total number of genes connected in the network 582 in each year was used as Fisher's exact test universe. For each year, a disease-disease 583 knowledge network was developed using the - $\log _{10}$ pval of the Fisher's exact test ("disease584 disease similarity") as the edge weight for each disease pair. The networks were constructed 585 using the R package igraph (Csardi and Nepusz, 2006) and plotted using the package ggraph. We detected new genes in each year by comparing the list of genes of the diseases in one year to the list of genes of the same disease in the previous year. Thus, we obtained a list of new genes that were added to the network in each year from 1991 to 2018 . The total number of genes associated with each disease was also calculated for each year. Line, violin, and ridge plots were created to illustrate the results using ggplot2 (Wickham, 2016).

591

\section{Evolution of disease relationships between categories}

For the top 9 diseases of each category that were connected to the most genes in 2018

594 ("top 9 diseases"), we detected the diseases from the other two categories with the most 595 significant gene sharing between them ("disease pairs") and analyzed how these relationships 596 evolved from 1990 to 2018. The disease-disease similarity scores obtained previously were also 597 used in this analysis. We used the MeSH.db R package (Tsuyuzaki et al., 2015) to obtain the $598 \mathrm{MeSH}$ IDs and terms of all 99 diseases. Using the obtained MeSH terms of the diseases in each 599 pair, we used the easyPubMed R package to search for PubMed papers in which both disease 600 MeSHes were found together. We then used an adapted version of the fetch_pubmed_data 601 function (see code in GitHub) of the easyPubMed package to retrieve the number of papers that 
medRxiv preprint doi: https://doi.org/10.1101/2021.06.16.21259049; this version posted June 21, 2021. The copyright holder for this preprint (which was not certified by peer review) is the author/funder, who has granted medRxiv a license to display the preprint in perpetuity.

It is made available under a CC-BY-NC-ND 4.0 International license .

602 contained the searched MeSH pairs in each year from 1990 to 2018 . We used the disease-

603 disease similarity score and the number of papers in 2018 to calculate a similarity-to-paper ratio

604 for each disease pair as follows:

$$
\text { similarity. paper. } \text { ratio }=\frac{\text { dis. dis. similarity }}{\text { numberofpapers }}
$$

605 Low similarity-to-paper ratios $(<10)$ were considered as cases of low knowledge gap between 606 the gene sharing and the general scientific interest in the disease pairs. Pairs in this category 607 included those in which the diseases did not share a significant amount of genes or pairs of 608 similar diseases for which there is also a proportional number of papers that cite the two 609 diseases together. Ratios between 10 and 40 were considered as cases of intermediate 610 knowledge gap, that is, the diseases in the pair are similar in the genes they share, but the 611 number of papers on the two diseases together is not proportionally high. High similarity-to612 paper ratios $(>40)$ were interpreted as cases of a large knowledge gap. The pairs that fell in this 613 category include diseases that share a significant proportion of their genes but that have almost 614 never been studied together, evidenced by the very low number of papers including the two 615 MeSH terms.

616

\section{Evolution of biological pathways}

618 We used the enricher function of the $\mathrm{R}$ package clusterProfiler (Yu et al., 2012) to 619 perform an ORA against Reactome pathways of the genes associated with the top 9 diseases of 620 each category in each year. We selected the significant Reactome pathways (p.adjust $<0.01)$ of 621 the top 9 diseases in 2018 and calculated the significance of the gene overlap between these 622 pathways with Fisher's exact test. We considered only the genes of each significant pathway 623 that were also present in the 2018 gene-disease network. By doing this, we limited pathways to 
medRxiv preprint doi: https://doi.org/10.1101/2021.06.16.21259049; this version posted June 21, 2021. The copyright holder for this preprint (which was not certified by peer review) is the author/funder, who has granted medRxiv a license to display the preprint in perpetuity.

It is made available under a CC-BY-NC-ND 4.0 International license .

624 cluster according to the genes shared from our data set, not all the genes in the pathways. We

625 then built a pathway network connecting the significant Reactome terms using the $-\log _{10}$ pvalue

626 of the Fisher's exact tests as edge weights, similar to what was done for the disease-disease

627 network in Fig. 1A. We detected clusters of pathways in this network using the cluster_louvain

628 function (Blondel et al., 2008) of the igraph R package (Csardi and Nepusz, 2006). Edge

629 weights were considered for the cluster detection. We calculated the weighted degree of each

630 pathway in the network using the strength function of the igraph package (Csardi and Nepusz,

631 2006). We manually annotated the detected clusters for their major biological function using the

632 pathways with the highest weighted degree in each cluster as reference. The significance

633 values $\left(-\log _{10} \mathrm{pval}\right)$ of ORA for the pathways in each cluster were used to make box and ridge

634 plots to illustrate the results for each disease in 2018 and how these results changed from 1990

635 to 2018.

636

637 Evolution of drug target hub genes

$638 \quad$ Using the 2018 gene-disease network, we detected the genes common to all three 639 categories of diseases ("hub genes"). We used the R package UpsetR to visualize the number 640 of genes shared and exclusive to the disease categories. We downloaded the drug-gene and

641 the drug-disease interaction databases from the CTD (http://ctdbase.org/; Davis et al., 2021).

642 We used the MeSH terms of the 99 diseases to filter the drug-disease database and kept only

643 interactions between drugs and diseases that were listed as "therapeutic" by CTD. These are

644 cases of a "chemical that has a known or potential therapeutic role in a disease (e.g., chemical

$645 \mathrm{X}$ is used to treat leukemia)", according to the CTD glossary (Davis et al., 2021). We filtered the

646 drug-gene database and kept only the interactions between the therapeutic drugs and the hub 
medRxiv preprint doi: https://doi.org/10.1101/2021.06.16.21259049; this version posted June 21, 2021. The copyright holder for this preprint (which was not certified by peer review) is the author/funder, who has granted medRxiv a license to display the preprint in perpetuity.

It is made available under a CC-BY-NC-ND 4.0 International license .

647 genes of our analysis. This final drug-gene list was used to detect the top 20 drugs that target

648 the most hub genes and the top 20 hub genes most targeted by the therapeutic drugs. We

649 visualized these drug-gene interactions in a network built with the $\mathrm{R}$ packages igraph and

650 plotted with ggplot2 and ggraph. We used the yearly gene-disease networks to detect when the

651 top 20 drug target hub genes were first connected to diseases in each category to build a 652 timeline.

653

654 Competing interests

655 We declare that the authors have no conflicts of interest.

656

657

Data availability

658

The data and code used to produce the analyses and figures in this study are available

659

at https://github.com/csbl-usp/evolution of knowledge.

660

661

Author Contribution

662

Conceptualization, Investigation, Data Curation and Writing: TLD, RJSD, PPA, VS, GRF

663 and HIN. Software Programming, Formal analysis: TLD, VS, TLA. Repository was developed by

664 TLD and TLA. Resources, Writing Review \& Editing: TLD, RJSD, PPA, VS, GRF and HIN;

665 Supervision and Funding acquisition: GRF and HIN.

666

\section{Funding}

668 This work was supported by Brazilian National Council for Scientific and Technological

669 Development (grant numbers 313662/2017-7); the São Paulo Research Foundation (grant 
medRxiv preprint doi: https://doi.org/10.1101/2021.06.16.21259049; this version posted June 21, 2021. The copyright holder for this preprint (which was not certified by peer review) is the author/funder, who has granted medRxiv a license to display the preprint in perpetuity.

It is made available under a CC-BY-NC-ND 4.0 International license.

670 numbers 2018/14933-2).

671 
medRxiv preprint doi: https://doi.org/10.1101/2021.06.16.21259049; this version posted June 21, 2021. The copyright holder for this preprint (which was not certified by peer review) is the author/funder, who has granted medRxiv a license to display the preprint in perpetuity.

\section{References}

673 Bai T, Gong L, Wang Ye, Wang Yan, Kulikowski CA, Huang L. 2016. A method for exploring

674

675 implicit concept relatedness in biomedical knowledge network. BMC Bioinformatics 17 Suppl 9:265. doi:10.1186/s12859-016-1131-5 Balak DM, Hajdarbegovic E. 2017. Drug-induced psoriasis: clinical perspectives. Psoriasis (Auckl) 7:87-94. doi:10.2147/PTT.S126727

678

679

680

681

682

683

684

685

686

687

688

689

690

691

692

693

694

695

696

697

698

699

700

701

702

703

704

705

706

707

708

709

710

711

Barabási A-L, Gulbahce N, Loscalzo J. 2011. Network medicine: a network-based approach to human disease. Nat Rev Genet 12:56-68. doi:10.1038/nrg2918

Ben-Zvi I, Kivity S, Langevitz P, Shoenfeld Y. 2012. Hydroxychloroquine: from malaria to autoimmunity. Clin Rev Allergy Immunol 42:145-153. doi:10.1007/s12016-010-8243-x

Blondel VD, Guillaume J-L, Lambiotte R, Lefebvre E. 2008. Fast unfolding of communities in large networks. J Stat Mech 2008:P10008. doi:10.1088/1742-5468/2008/10/P10008

Brew BJ, Garber JY. 2018. Neurologic sequelae of primary HIV infection. Handb Clin Neurol 152:65-74. doi:10.1016/B978-0-444-63849-6.00006-2

Brooks PJ, Tagle DA, Groft S. 2014. Expanding rare disease drug trials based on shared molecular etiology. Nat Biotechnol 32:515-518. doi:10.1038/nbt.2924

Carson MB, Liu C, Lu Y, Jia C, Lu H. 2017. A disease similarity matrix based on the uniqueness of shared genes. BMC Med Genomics 10:26. doi:10.1186/s12920-017-0265-2

Chateauvieux S, Morceau F, Dicato M, Diederich M. 2010. Molecular and therapeutic potential and toxicity of valproic acid. J Biomed Biotechnol 2010. doi:10.1155/2010/479364

Chaudhry IB, Husain MO, Khoso AB, Husain MI, Buch MH, Kiran T, Fu B, Bassett P, Qurashi I, Ur Rahman R, Baig S, Kazmi A, Corsi-Zuelli F, Haddad PM, Deakin B, Husain N. 2020. A randomised clinical trial of methotrexate points to possible efficacy and adaptive immune dysfunction in psychosis. Trans/ Psychiatry 10:415. doi:10.1038/s41398-020-01095-8

Chen H, Liu S, Ji L, Wu T, Ji Y, Zhou Y, Zheng M, Zhang M, Xu W, Huang G. 2016. Folic acid supplementation mitigates alzheimer's disease by reducing inflammation: A randomized controlled trial. Mediators Inflamm 2016:5912146. doi:10.1155/2016/5912146

Chen S, Ye J, Chen X, Shi J, Wu W, Lin Wenping, Lin Weibin, Li Y, Fu H, Li S. 2018. Valproic acid attenuates traumatic spinal cord injury-induced inflammation via STAT1 and NF-kB pathway dependent of HDAC3. J Neuroinflammation 15:150. doi:10.1186/s12974-0181193-6

Chen Y, Elenee Argentinis JD, Weber G. 2016. IBM watson: how cognitive computing can be applied to big data challenges in life sciences research. Clin Ther 38:688-701. doi:10.1016/j.clinthera.2015.12.001

Chen Y-L, Jing J, Mo Y-Q, Ma J-D, Yang L-J, Chen L-F, Zhang X, Yan T, Zheng D-H, Pessler F, Dai L. 2018. Presence of hepatitis $B$ virus in synovium and its clinical significance in rheumatoid arthritis. Arthritis Res Ther 20:130. doi:10.1186/s13075-018-1623-y Clayton KA, Van Enoo AA, Ikezu T. 2017. Alzheimer's disease: the role of microglia in brain homeostasis and proteopathy. Front Neurosci 11:680. doi:10.3389/fnins.2017.00680

Costalonga EC, Silva FMO, Noronha IL. 2016. Valproic Acid Prevents Renal Dysfunction and 
medRxiv preprint doi: https://doi.org/10.1101/2021.06.16.21259049; this version posted June 21, 2021. The copyright holder for this preprint (which was not certified by peer review) is the author/funder, who has granted medRxiv a license to display the preprint in perpetuity. It is made available under a CC-BY-NC-ND 4.0 International license .

712

713

714

715

716

717

718

719

720

721

722

723

724

725

726

727

728

729

730

731

732

733

734

735

736

737

738

739

740

741

742

743

744

745

746

747

748

749

750

751

Inflammation in the Ischemia-Reperfusion Injury Model. Biomed Res Int 2016:5985903. doi:10.1155/2016/5985903

Csardi G, Nepusz T. 2006. The igraph software package for complex network research. InterJournal Complex Systems:1695.

Dalakas MC. 2020. Guillain-Barré syndrome: The first documented COVID-19-triggered autoimmune neurologic disease: More to come with myositis in the offing. Neurol Neuroimmunol Neuroinflamm 7. doi:10.1212/NXI.0000000000000781

Davis AP, Grondin CJ, Johnson RJ, Sciaky D, Wiegers J, Wiegers TC, Mattingly CJ. 2021. Comparative Toxicogenomics Database (CTD): update 2021. Nucleic Acids Res 49:D1138-D1143. doi:10.1093/nar/gkaa891

de Baumont A, Maschietto M, Lima L, Carraro DM, Olivieri EH, Fiorini A, Barreta LAN, Palha JA, Belmonte-de-Abreu P, Moreira Filho CA, Brentani H. 2015. Innate immune response is differentially dysregulated between bipolar disease and schizophrenia. Schizophr Res 161:215-221. doi:10.1016/j.schres.2014.10.055

De Felice C, Leoncini S, Signorini C, Cortelazzo A, Rovero P, Durand T, Ciccoli L, Papini AM, Hayek J. 2016. Rett syndrome: An autoimmune disease? Autoimmun Rev 15:411-416. doi:10.1016/j.autrev.2016.01.011

Dong D, Zielke HR, Yeh D, Yang P. 2018. Cellular stress and apoptosis contribute to the pathogenesis of autism spectrum disorder. Autism Res 11:1076-1090. doi:10.1002/aur.1966

Dong Y, Lagarde J, Xicota L, Corne H, Chantran Y, Chaigneau T, Crestani B, Bottlaender M, Potier M-C, Aucouturier P, Dorothée G, Sarazin M, Elbim C. 2018. Neutrophil hyperactivation correlates with Alzheimer's disease progression. Ann Neurol 83:387-405. doi:10.1002/ana.25159

Dugger BN, Dickson DW. 2017. Pathology of neurodegenerative diseases. Cold Spring Harb Perspect Bio/ 9. doi:10.1101/cshperspect.a028035

Eimer WA, Vijaya Kumar DK, Navalpur Shanmugam NK, Rodriguez AS, Mitchell T, Washicosky KJ, György B, Breakefield XO, Tanzi RE, Moir RD. 2018. Alzheimer's Disease-Associated $\beta$-Amyloid Is Rapidly Seeded by Herpesviridae to Protect against Brain Infection. Neuron 100:1527-1532. doi:10.1016/j.neuron.2018.11.043

Fortunato S, Bergstrom CT, Börner K, Evans JA, Helbing D, Milojević S, Petersen AM, Radicchi F, Sinatra R, Uzzi B, Vespignani A, Waltman L, Wang D, Barabási A-L. 2018. Science of science. Science 359. doi:10.1126/science.aao0185

Galvez-Sánchez CM, Montoro CI, Duschek S, Reyes Del Paso GA. 2020. Depression and traitanxiety mediate the influence of clinical pain on health-related quality of life in fibromyalgia. J Affect Disord 265:486-495. doi:10.1016/j.jad.2020.01.129

Gandal MJ, Zhang P, Hadjimichael E, Walker RL, Chen C, Liu S, Won H, van Bakel H, Varghese M, Wang Y, Shieh AW, Haney J, Parhami S, Belmont J, Kim M, Moran Losada P, Khan Z, Mleczko J, Xia Y, Dai R, Geschwind DH. 2018. Transcriptome-wide isoform-level dysregulation in ASD, schizophrenia, and bipolar disorder. Science 362. 
medRxiv preprint doi: https://doi.org/10.1101/2021.06.16.21259049; this version posted June 21, 2021. The copyright holder for this preprint (which was not certified by peer review) is the author/funder, who has granted medRxiv a license to display the preprint in perpetuity.

doi:10.1126/science.aat8127

753

754

755

756

757

758

759

760

761

762

763

764

765

766

767

768

769

770

771

772

773

774

775

776

777

778

779

780

781

782

783

784

785

786

787

788

789

790

791

Getts DR, Chastain EML, Terry RL, Miller SD. 2013. Virus infection, antiviral immunity, and autoimmunity. Immunol Rev 255:197-209. doi:10.1111/imr.12091

Gibney SM, Drexhage HA. 2013. Evidence for a dysregulated immune system in the etiology of psychiatric disorders. J Neuroimmune Pharmacol 8:900-920. doi:10.1007/s11481-0139462-8

Goodwin DG, Strobl J, Mitchell SM, Zajac AM, Lindsay DS. 2008. Evaluation of the moodstabilizing agent valproic acid as a preventative for toxoplasmosis in mice and activity against tissue cysts in mice. J Parasitol 94:555-557. doi:10.1645/GE-1331.1

Göttlicher M, Minucci S, Zhu P, Krämer OH, Schimpf A, Giavara S, Sleeman JP, Lo Coco F, Nervi C, Pelicci PG, Heinzel T. 2001. Valproic acid defines a novel class of HDAC inhibitors inducing differentiation of transformed cells. EMBO J 20:6969-6978. doi:10.1093/emboj/20.24.6969

Gravani A, Gaitanis G, Zioga A, Bassukas ID. 2014. Synthetic antimalarial drugs and the triggering of psoriasis - do we need disease-specific guidelines for the management of patients with psoriasis at risk of malaria? Int $J$ Dermatol 53:327-330. doi:10.1111/ijd.12231

Hammer SM, Katzenstein DA, Hughes MD, Gundacker H, Schooley RT, Haubrich RH, Henry WK, Lederman MM, Phair JP, Niu M, Hirsch MS, Merigan TC. 1996. A trial comparing nucleoside monotherapy with combination therapy in HIV-infected adults with CD4 cell counts from 200 to 500 per cubic millimeter. AIDS Clinical Trials Group Study 175 Study Team. N Engl J Med 335:1081-1090. doi:10.1056/NEJM199610103351501

Harris SA, Harris EA. 2015. Herpes simplex virus type 1 and other pathogens are key causative factors in sporadic alzheimer's disease. J Alzheimers Dis 48:319-353. doi:10.3233/JAD142853

Hull EE, Montgomery MR, Leyva KJ. 2016. HDAC inhibitors as epigenetic regulators of the immune system: impacts on cancer therapy and inflammatory diseases. Biomed Res Int 2016:8797206. doi:10.1155/2016/8797206

Hwang ES. 2010. Transcriptional regulation of T helper 17 cell differentiation. Yonsei Med J 51:484-491. doi:10.3349/ymj.2010.51.4.484

Kohler O, Krogh J, Mors O, Benros ME. 2016. Inflammation in Depression and the Potential for Anti-Inflammatory Treatment. Curr Neuropharmacol 14:732-742.

doi:10.2174/1570159x14666151208113700

Lander ES, Linton LM, Birren B, Nusbaum C, Zody MC, Baldwin J, Devon K, Dewar K, Doyle M, FitzHugh W, Funke R, Gage D, Harris K, Heaford A, Howland J, Kann L, Lehoczky J, LeVine R, McEwan P, McKernan K, et al. 2001. Initial sequencing and analysis of the human genome. Nature 409:860-921. doi:10.1038/35057062

Langrish CL, Chen Y, Blumenschein WM, Mattson J, Basham B, Sedgwick JD, McClanahan T, Kastelein RA, Cua DJ. 2005. IL-23 drives a pathogenic T cell population that induces autoimmune inflammation. J Exp Med 201:233-240. doi:10.1084/jem.20041257

Lees CW, Barrett JC, Parkes M, Satsangi J. 2011. New IBD genetics: common pathways with 
medRxiv preprint doi: https://doi.org/10.1101/2021.06.16.21259049; this version posted June 21, 2021. The copyright holder for this preprint (which was not certified by peer review) is the author/funder, who has granted medRxiv a license to display the preprint in perpetuity.

792

793

794

795

796

797

798

799

800

801

802

803

804

805

806

807

808

809

810

811

812

813

814

815

816

817

818

819

820

821

822

823

824

825

826

827

828

829

830

831

other diseases. Gut 60:1739-1753. doi:10.1136/gut.2009.199679

Leonard BE. 2018. Inflammation and depression: a causal or coincidental link to the pathophysiology? Acta Neuropsychiatr 30:1-16. doi:10.1017/neu.2016.69

Li H-M, Huang Y-K, Su Y-C, Kao C-H. 2018. Increased risk of autoimmune diseases in dengue patients: A population-based cohort study. J Infect 77:212-219. doi:10.1016/j.jinf.2018.03.014

Littmann M, Selig K, Cohen-Lavi L, Frank Y, Hönigschmid P, Kataka E, Mösch A, Qian K, Ron A, Schmid S, Sorbie A, Szlak L, Dagan-Wiener A, Ben-Tal N, Niv MY, Razansky D, Schuller BW, Ankerst D, Hertz T, Rost B. 2020. Validity of machine learning in biology and medicine increased through collaborations across fields of expertise. Nat Mach Intell. doi:10.1038/s42256-019-0139-8

Liyanage VRB, Rastegar M. 2014. Rett syndrome and MeCP2. Neuromolecular Med 16:231264. doi:10.1007/s12017-014-8295-9

Lüscher Dias T, Schuch V, Beltrão-Braga PCB, Martins-de-Souza D, Brentani HP, Franco GR, Nakaya HI. 2020. Drug repositioning for psychiatric and neurological disorders through a network medicine approach. Transl Psychiatry 10:141. doi:10.1038/s41398-020-0827-5

Madore C, Leyrolle Q, Lacabanne C, Benmamar-Badel A, Joffre C, Nadjar A, Layé S. 2016. Neuroinflammation in autism: plausible role of maternal inflammation, dietary omega 3 , and microbiota. Neural Plast 2016:3597209. doi:10.1155/2016/3597209

Margulies M, Egholm M, Altman WE, Attiya S, Bader JS, Bemben LA, Berka J, Braverman MS, Chen Y-J, Chen Z, Dewell SB, Du L, Fierro JM, Gomes XV, Godwin BC, He W, Helgesen S, Ho CH, Irzyk GP, Jando SC, Rothberg JM. 2005. Genome sequencing in microfabricated high-density picolitre reactors. Nature 437:376-380. doi:10.1038/nature03959

Marks M, Marks JL. 2016. Viral arthritis. Clin Med 16:129-134. doi:10.7861/clinmedicine.16-2129

Marrie RA, Walld R, Bolton JM, Sareen J, Walker JR, Patten SB, Singer A, Lix LM, Hitchon CA, El-Gabalawy R, Katz A, Fisk JD, Bernstein CN, ClHR Team in Defining the Burden and Managing the Effects of Psychiatric Comorbidity in Chronic Immunoinflammatory Disease. 2017. Increased incidence of psychiatric disorders in immune-mediated inflammatory disease. J Psychosom Res 101:17-23. doi:10.1016/j.jpsychores.2017.07.015

Mirise RT, Kitridou RC. 1979. Arthritis and hepatitis. West J Med 130:12-17.

Nalbant A, Eskier D. 2016. Genes associated with T helper 17 cell differentiation and function. Front Biosci (Elite Ed) 8:427-435. doi:10.2741/e777

Newcombe EA, Camats-Perna J, Silva ML, Valmas N, Huat TJ, Medeiros R. 2018. Inflammation: the link between comorbidities, genetics, and Alzheimer's disease. $J$ Neuroinflammation 15:276. doi:10.1186/s12974-018-1313-3

Nygaard G, Firestein GS. 2020. Restoring synovial homeostasis in rheumatoid arthritis by targeting fibroblast-like synoviocytes. Nat Rev Rheumatol 16:316-333.

doi:10.1038/s41584-020-0413-5 
medRxiv preprint doi: https://doi.org/10.1101/2021.06.16.21259049; this version posted June 21, 2021. The copyright holder for this preprint (which was not certified by peer review) is the author/funder, who has granted medRxiv a license to display the preprint in perpetuity.

832

833

834

835

836

837

838

839

840

841

842

843

844

845

846

847

848

849

850

851

852

853

854

855

856

857

858

859

860

861

862

863

864

865

866

867

868

869

870

871

Ozben T, Ozben S. 2019. Neuro-inflammation and anti-inflammatory treatment options for Alzheimer's disease. Clin Biochem 72:87-89. doi:10.1016/j.clinbiochem.2019.04.001 Pandurangi AK, Buckley PF. 2020. Inflammation, Antipsychotic Drugs, and Evidence for Effectiveness of Anti-inflammatory Agents in Schizophrenia. Curr Top Behav Neurosci 44:227-244. doi:10.1007/7854_2019_91

Pitt B, Sutton NR, Wang Z, Goonewardena SN, Holinstat M. 2021. Potential repurposing of the HDAC inhibitor valproic acid for patients with COVID-19. Eur J Pharmacol 898:173988. doi:10.1016/j.ejphar.2021.173988

Postma DS, Kerkhof M, Boezen HM, Koppelman GH. 2011. Asthma and chronic obstructive pulmonary disease: common genes, common environments? Am J Respir Crit Care Med 183:1588-1594. doi:10.1164/rccm.201011-1796PP

Rajkomar A, Oren E, Chen K, Dai AM, Hajaj N, Hardt M, Liu PJ, Liu X, Marcus J, Sun M, Sundberg P, Yee H, Zhang K, Zhang Y, Flores G, Duggan GE, Irvine J, Le Q, Litsch K, Mossin A, Dean J. 2018. Scalable and accurate deep learning with electronic health records. npj Digital Med 1:18. doi:10.1038/s41746-018-0029-1

RECOVERY Collaborative Group, Horby P, Lim WS, Emberson JR, Mafham M, Bell JL, Linsell L, Staplin N, Brightling C, Ustianowski A, Elmahi E, Prudon B, Green C, Felton T, Chadwick D, Rege K, Fegan C, Chappell LC, Faust SN, Jaki T, Landray MJ. 2021. Dexamethasone in Hospitalized Patients with Covid-19. N Engl J Med 384:693-704.

doi:10.1056/NEJMoa2021436

Rosenblat JD, Kakar R, Berk M, Kessing LV, Vinberg M, Baune BT, Mansur RB, Brietzke E, Goldstein BI, Mclntyre RS. 2016. Anti-inflammatory agents in the treatment of bipolar depression: a systematic review and meta-analysis. Bipolar Disord 18:89-101. doi:10.1111/bdi.12373

Scuderi C, Verkhratsky A. 2020. The role of neuroglia in autism spectrum disorders. Prog Mol Biol Trans/ Sci 173:301-330. doi:10.1016/bs.pmbts.2020.04.011

Sethi MK, Zaia J. 2017. Extracellular matrix proteomics in schizophrenia and Alzheimer's disease. Anal Bioanal Chem 409:379-394. doi:10.1007/s00216-016-9900-6

Shi X, Liu Y, Zhang D, Xiao D. 2019. Valproic acid attenuates sepsis-induced myocardial dysfunction in rats by accelerating autophagy through the PTEN/AKT/mTOR pathway. Life Sci 232:116613. doi:10.1016/j.lfs.2019.116613

Tomson T, Battino D, Perucca E. 2016. The remarkable story of valproic acid. Lancet Neurol 15:141. doi:10.1016/S1474-4422(15)00398-1

Tshitoyan V, Dagdelen J, Weston L, Dunn A, Rong Z, Kononova O, Persson KA, Ceder G, Jain A. 2019. Unsupervised word embeddings capture latent knowledge from materials science literature. Nature 571:95-98. doi:10.1038/s41586-019-1335-8

Tsuyuzaki K, Morota G, Ishii M, Nakazato T, Miyazaki S, Nikaido I. 2015. MeSH ORA framework: R/Bioconductor packages to support MeSH over-representation analysis. BMC Bioinformatics 16:45. doi:10.1186/s12859-015-0453-z

Venter JC, Adams MD, Myers EW, Li PW, Mural RJ, Sutton GG, Smith HO, Yandell M, Evans 
medRxiv preprint doi: https://doi.org/10.1101/2021.06.16.21259049; this version posted June 21, 2021. The copyright holder for this preprint (which was not certified by peer review) is the author/funder, who has granted medRxiv a license to display the preprint in perpetuity. It is made available under a CC-BY-NC-ND 4.0 International license .

872 CA, Holt RA, Gocayne JD, Amanatides P, Ballew RM, Huson DH, Wortman JR, Zhang Q,

873

874

875

876

877

878

879

880

881

882

883

884

885

886

887

888

889

890
Kodira CD, Zheng XH, Chen L, Skupski M, et al. 2001. The sequence of the human genome. Science 291:1304-1351. doi:10.1126/science.1058040

Wang Q, Yang C, Gelernter J, Zhao H. 2015. Pervasive pleiotropy between psychiatric disorders and immune disorders revealed by integrative analysis of multiple GWAS. Hum Genet 134:1195-1209. doi:10.1007/s00439-015-1596-8

Wickham H. 2016. ggplot2 - Elegant Graphics for Data Analysis, 2nd ed. Cham: Springer International Publishing. doi:10.1007/978-3-319-24277-4

Yuan N, Chen Y, Xia Y, Dai J, Liu C. 2019. Inflammation-related biomarkers in major psychiatric disorders: a cross-disorder assessment of reproducibility and specificity in 43 metaanalyses. Trans/ Psychiatry 9:233. doi:10.1038/s41398-019-0570-y

Yu G, Wang L-G, Han Y, He Q-Y. 2012. clusterProfiler: an R package for comparing biological themes among gene clusters. OMICS 16:284-287. doi:10.1089/omi.2011.0118

Zambrano-Zaragoza JF, Romo-Martínez EJ, Durán-Avelar M de J, García-Magallanes N, Vibanco-Pérez N. 2014. Th17 cells in autoimmune and infectious diseases. Int J Inflam 2014:651503. doi:10.1155/2014/651503

Zitnik M, Nguyen F, Wang B, Leskovec J, Goldenberg A, Hoffman MM. 2019. Machine learning for integrating data in biology and medicine: principles, practice, and opportunities. Inf Fusion 50:71-91. doi:10.1016/j.inffus.2018.09.012 